\title{
Two-Photon Imaging of Nonlinear Glutamate Release Dynamics at Bipolar Cell Synapses in the Mouse Retina
}

\author{
Bart G. Borghuis, ${ }^{1,3}$ Jonathan S. Marvin, ${ }^{3}$ Loren L. Looger, ${ }^{3}$ and Jonathan B. Demb ${ }^{1,2}$ \\ ${ }^{1}$ Department of Ophthalmology \& Visual Science and ${ }^{2}$ Department of Cellular \& Molecular Physiology, Yale University School of Medicine, New Haven, \\ Connecticut 06511, and ${ }^{3}$ Howard Hughes Medical Institute, Janelia Farm Research Campus, Ashburn, Virginia 20147
}

\begin{abstract}
Alpha/Y-type retinal ganglion cells encode visual information with a receptive field composed of nonlinear subunits. This nonlinear subunit structure enhances sensitivity to patterns composed of high spatial frequencies. The Y-cell's subunits are the presynaptic bipolar cells, but the mechanism for the nonlinearity remains incompletely understood. We investigated the synaptic basis of the subunit nonlinearity by combining whole-cell recording of mouse Y-type ganglion cells with two-photon fluorescence imaging of a glutamate sensor (iGluSnFR) expressed on their dendrites and throughout the inner plexiform layer. A control experiment designed to assess iGluSnFR's dynamic range showed that fluorescence responses from Y-cell dendrites increased proportionally with simultaneously recorded excitatory current. Spatial resolution was sufficient to readily resolve independent release at intermingled ON and OFF bipolar terminals. iGluSnFR responses at Y-cell dendrites showed strong surround inhibition, reflecting receptive field properties of presynaptic release sites. Responses to spatial patterns located the origin of the Y-cell nonlinearity to the bipolar cell output, after the stage of spatial integration. The underlying mechanism differed between OFF and ON pathways: OFF synapses showed transient release and strong rectification, whereas $\mathrm{ON}$ synapses showed relatively sustained release and weak rectification. At $\mathrm{ON}$ synapses, the combination of fast release onset with slower release offset explained the nonlinear response of the postsynaptic ganglion cell. Imaging throughout the inner plexiform layer, we found transient, rectified release at the central-most levels, with increasingly sustained release near the borders. By visualizing glutamate release in real time, iGluSnFR provides a powerful tool for characterizing glutamate synapses in intact neural circuits.
\end{abstract}

\section{Introduction}

Retinal ganglion cells divide into 20 types based on a combination of functional and morphological criteria (Field and Chichilnisky, 2007; Masland, 2012). In many types, the receptive field comprises a nonlinear subunit structure (Enroth-Cugell and Robson, 1966; Hochstein and Shapley, 1976; Caldwell and Daw, 1978; Troy et al., 1989; Stone and Pinto, 1993; Troy et al., 1995; Demb et al., 2001b; Crook et al., 2008; Estevez et al., 2012). Each subunit encodes local contrast, and the output is transformed nonlinearly before integration of multiple subunits by the ganglion cell (Brown and Masland, 2001; Schwartz and Rieke, 2011; Garvert and Gollisch, 2013). The nonlinear transformation allows individual subunits to encode their preferred contrast polarity (light increment or decrement) without being canceled by neighboring subunits stimulated with the opposite polarity.

Received March 22, 2013; revised May 1, 2013; accepted May 21, 2013.

Author contributions: B.G.B. and J.B.D. designed research; B.G.B. performed research; J.S.M. and L.L.L. contributed unpublished reagents/analytic tools; B.G.B. analyzed data; B.G.B., L.L.L., and J.B.D. wrote the paper.

This work was supported by National Institutes of Health Grant R01 EY014454 to J.B.D. and Grant R21 EY023038 to B.G.B. and J.B.D. and the Howard Hughes Medical Institute to J.S.M. and L.L.L.

B.G.B. owns Borghuis Instruments. Borghuis Instruments sells the specialized syringe that was used for intravitreal virus injections in this study. The remaining authors declare no competing financial interests. We thank Karel Svoboda (HHMI, Janelia Farm Research Campus) for technical advice.

Correspondence should be addressed to either Dr. Bart G. Borghuis or Dr. Jonathan B. Demb, Department of Ophthalmology \& Visual Science, Yale University School of Medicine, 300 George Street, Suite 8100, New Haven, CT 06511. E-mail: bart.borghuis@yale.edu or jonathan.demb@yale.edu.

DOI:10.1523/JNEUROSCI.1241-13.2013

Copyright $\odot 2013$ the authors $\quad 0270-6474 / 13 / 3310972-14 \$ 15.00 / 0$
A characteristic property of a nonlinear subunit receptive field, exemplified by $\alpha / Y$-type ganglion cells (Y-cells), is the frequency-doubled response to a contrast-reversing grating (Hochstein and Shapley, 1976; Demb et al., 1999) (Fig. 1). Nonlinear subunits explain the ganglion cell response to specific visual features, including high spatial frequency textures, differential motion, second-order motion, and motion onset (Victor and Shapley, 1979; Demb et al., 2001a; Olveczky et al., 2003, 2007; Baccus et al., 2008; Schwartz et al., 2012; Chen et al., 2013). However, the exact nature of the nonlinearity remains unknown, and direct measurements of nonlinear subunits converging on a ganglion cell have been lacking.

The cellular basis for the nonlinear subunits appears to be the bipolar cells: the nonlinear response depends on glutamate receptors but not acetylcholine or inhibitory receptors (Demb et al., 2001b), and the subunits are narrow, matching the bipolar cell receptive field (Berntson and Taylor, 2000; Dacey et al., 2000; Schwartz et al., 2012). The principal nonlinearity in the bipolar cell output could originate at the level of presynaptic cone photoreceptors (Gaudiano, 1992; Schneeweis and Schnapf, 1999; Hennig et al., 2002; Jackman et al., 2009) or, more likely, at the level of the bipolar axon terminal (Olveczky et al., 2007; Baccus et al., 2008; Schwartz et al., 2012). Nonlinearity at the axon terminal supposedly follows from transient glutamate release combined with a low basal rate, which causes rectification (Roska and Werblin, 2001; Jarsky et al., 2011; Baden et al., 2013). However, tonic excitatory currents measured in ON Y-cells suggest that presyn- 


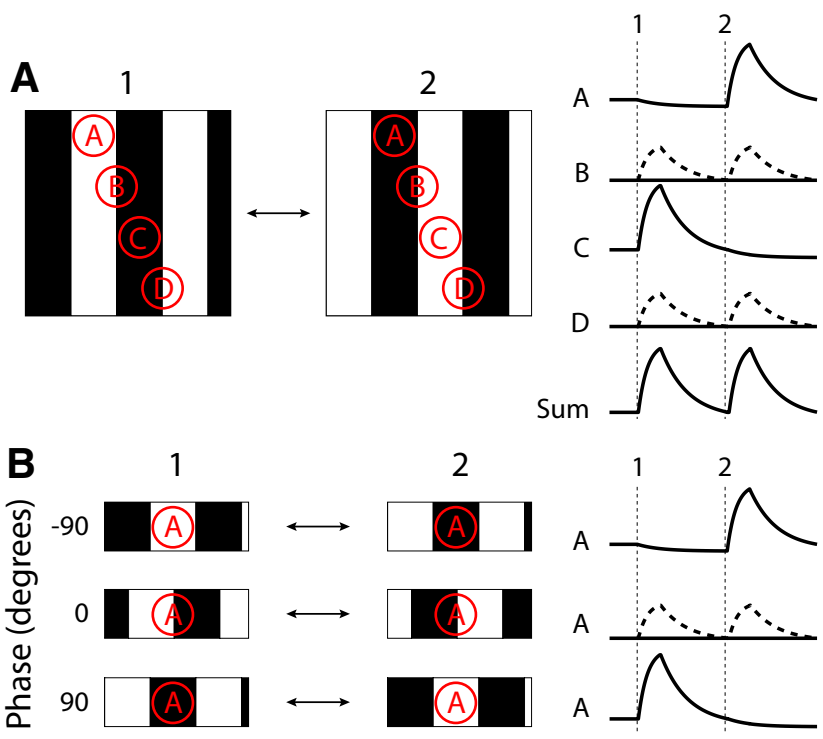

Figure 1. Nonlinear release from bipolar cells explains frequency-doubled responses. $\boldsymbol{A}$, Model for the Y-cell nonlinearity in ganglion cells. The subunits (OFF bipolar cells A-D) view a contrast-reversing grating (alternating between frames 1 and 2 ) and respond to the preferred contrast. If the nonlinear transformation occurred after linear integration of contrast, the bipolar cell response would be canceled when equal amounts of dark and light cover the receptive field (null phase, solid line, subunits B and D). If, instead, the nonlinearity occurred before contrast integration, the bipolar cell response would be frequency-doubled at the null phase (dashed line). In both cases, the postsynaptic ganglion cell sums the subunits and generates a frequency-doubled response. $\boldsymbol{B}$, For a given subunit, the nonlinear response shown in $\boldsymbol{A}$ changes depending on the spatial phase of the grating.

aptic ON bipolar cells have a relatively high level of basal glutamate release and minimal rectification (Zaghloul et al., 2003; Manookin et al., 2008; Trong and Rieke, 2008), challenging the aforementioned model for the Y-cell nonlinearity.

To resolve the synaptic basis of the nonlinear subunits, we would ideally directly measure glutamate release from bipolar cells at multiple spatial locations on a fast time scale. Here, we used two-photon imaging of a genetically encoded glutamate sensor with fast temporal kinetics and high signal-to-noise ratio (Marvin et al., 2013). Direct measurements of glutamate release dynamics explain nonlinear Y-cell receptive fields, including cases where release is neither transient nor strongly rectified.

\section{Materials and Methods}

Retinal preparation. Retinas were prepared using the methods of Borghuis et al. (2011). All procedures were conducted in accordance with National Institutes of Health guidelines under protocols approved by the Yale University Animal Care and Use Committee. A 0.8-1.0 $\mu$ l volume of AAV2/1.hSynapsin.iGluSnFR in $\mathrm{H}_{2} \mathrm{O}\left(0.8-3.0 \times 10^{13} \mathrm{IU} / \mu \mathrm{l}\right)$ was injected into the vitreous humor of adult mouse eyes (C57/B6 J; 2-6 months old; both sexes) using a custom-designed syringe (Borghuis Instruments). This construct broadly targeted iGluSnFR to ganglion cells and amacrine cells. One experiment used AAV2/1.GFAP.iGluSnFR to selectively target Müller glia (see Fig. $2 H$ ). Between 14 and $21 \mathrm{~d}$ after injection, animals were killed and the eyes dissected in oxygenated Ames medium (95\% $\mathrm{O}_{2}-5 \% \mathrm{CO}_{2}$; Sigma-Aldrich). The retina was removed from the sclera under a dissection microscope equipped with infrared viewers (OWL Night Vision Scopes, third generation; B. E. Meyers). The retina was then mounted on perforated filter paper $(1.0-\mathrm{mm}$-diameter holes) and placed under a tissue harp in a perfusion chamber on a custom-built two-photon fluorescence microscope (Olympus BX-51; Olympus). Retinas were continuously perfused with oxygenated Ames medium at physiological temperature $\left(\sim 6 \mathrm{ml} / \mathrm{min} ; 34-36^{\circ} \mathrm{C}\right)$.
Fluorescence imaging and visual stimulation. Two-photon fluorescence measurements were made using an Olympus $60 \times, 0.9 \mathrm{NA}$, LUMPlanFl/IR objective (Olympus) and an ultrafast pulsed laser (Chameleon Ultra II; Coherent) tuned to $910 \mathrm{~nm}$. The microscope system was controlled by ScanImage software version 3.7 (www.scanimage.org). Images $(512 \times 128$ pixels) were acquired at 16 frames per second; line scans were obtained at $2 \mathrm{kHz}$ and down-sampled to $500 \mathrm{~Hz}$ for presentation in Figure 7 (box-car average).

Visual stimuli were generated using custom-written software (StimDemo, C language) and presented with a video projector (M109s DLP; Dell, or identical HP Notebook Companion; HP), modified to project UV light (single LED NC4U134A, peak wavelength $385 \mathrm{~nm}$; Nichia). Filtering by the projector's optics shifted the peak wavelength of stimulation to $395 \mathrm{~nm}$. This wavelength is approximately equally efficient at stimulating the $\mathrm{M}$ and S photopigments ( $\sim 20 \%$ of peak absorption for both), which are coexpressed in most cones throughout the retina with a dorsal-ventral gradient: $\mathrm{M}$ expression is highest in dorsal retina and $\mathrm{S}$ expression is highest in ventral retina (Szel et al., 1992; Nikonov et al., 2006; Breuninger et al., 2011; Wang et al., 2011; Chang et al., 2013). Thus, the 395 wavelength drives the coexpressing cones approximately equally, regardless of spatial position on the retina. Most experiments were performed in the ventral retina, and recordings in a given region were performed for up to $1 \mathrm{~h}$ without obvious decrement in light sensitivity.

Mean luminance at the retina $\left(5.8 \times 10^{4}\right.$ photons $\left./ \mu \mathrm{m}^{2} / \mathrm{s}\right)$ evoked $\sim 10^{4}$ photoisomerizations $\left(\mathrm{R}^{\star}\right)$ per second in rods, coexpressing cones and pure $S$ cones (Haverkamp et al., 2005). These estimates assume a 0.85 $\mu \mathrm{m}^{2}$ collecting area for rods and $1 \mu \mathrm{m}^{2}$ collecting area for cones (Wang et al., 2011). Neutral density filters (Kodak Wratten 2.0 ND; Edmund Optics) and a $440 \mathrm{~nm}$ short-pass dichroic filter (Semrock) rendered residual stimulus light entering the photon multiplier tubes undetectable against the baseline fluorescence of iGluSnFR-labeled processes. Size of the projected image on the retina was $2.1 \times 2.8 \mathrm{~mm}$. Stimuli were contrast-reversing spots and square-wave gratings. Data were analyzed with custom algorithms in MATLAB (The MathWorks).

To determine rod contributions to the responses in the presence of the scanning laser, we performed whole-cell recordings in retinas lacking functional cones (Gnat2 ${ }^{\mathrm{cpfl} 3}$ mouse, 10 months old; Chang et al., 2006). Three Y-cells (2 ON, 1 OFF-type; see definition below) showed similar results; an example cell is shown in Figure $2 \mathrm{~F}$. In response to a spot stimulus ( $1 \mathrm{~Hz}$ modulation; $400 \mu \mathrm{m}$ diameter; $100 \%$ contrast) at a dim mean luminance $\left(10^{2} \mathrm{R}^{\star} / \mathrm{rod} / \mathrm{s}\right)$, the excitatory current of an ON Y-cell was initially large (peak-to-trough response $\sim 1 \mathrm{nA}$ or greater; "pre" recording). When the laser turned on, the cell responded with an inward current, and there was no additional response to spot modulation (i.e., the laser saturated the response at this mean level). At the brighter level used for our primary experiments $\left(10^{4} \mathrm{R}^{\star} / \mathrm{rod} / \mathrm{s}\right)$, responses with and without the laser were both weak, and the response to laser onset was absent. Subsequently, a response to the original light stimulus returned, indicating that laser stimulation did not bleach the rods ("post" recording; Fig. 2F). Thus, in the experiments described below, at the mean luminance of $\sim 10^{4} \mathrm{R}^{\star} /$ photoreceptor/s, the response to laser onset and the light stimulus were almost exclusively mediated by cones (Naarendorp et al., 2010).

Visual stimuli were projected onto the retina through the microscope's condenser. Because the retina was mounted photoreceptor side down, stimulus light entered the photoreceptors in the opposite direction compared with the direction in vivo. To determine whether the direction of photon entry into the photoreceptors affected the light response, we positioned identical LEDs symmetrically above and below the retina and compared responses to flashes delivered from the ganglion cell versus the photoreceptor side. Loose-patch spike recordings of ganglion cell responses to brief flashes of increasing intensity (100 ms duration; $150 \mathrm{~ms}$ response window) showed that the average response to stimulation from above (ganglion cell side) and below the retina (photoreceptor side) was the same (mean difference $0.2 \pm 3.8 \%$, mean \pm SD; $n=11$ cells).

Whole-cell recordings and definition of cell type. Borosilicate glass patch electrodes (5-8 M $\Omega$ ) were filled with the following intracellular solution (in mM): 120 Cs-methanesulfonate, 5 TEA-Cl, 10 HEPES, 10 BAPTA, 3 $\mathrm{NaCl}, 2$ QX-314-Cl, 4 ATP-Mg, 0.4 GTP-Na $\mathrm{N}_{2}$, and 10 phosphocreatine- 
Tris $_{2}$ (pH 7.3, 280 mOsm). Excitatory currents were recorded with a holding potential near $\mathrm{E}_{\mathrm{Cl}}(-67 \mathrm{mV})$ after correcting for the liquid junction potential $(-9 \mathrm{mV})$. We targeted $\mathrm{Y} / \alpha$-type ganglion cells by recording from large somas (20-25 $\mu \mathrm{m}$ diameter) in the ganglion cell layer, using infrared wide-field imaging. Recorded cells were confirmed as $Y / \alpha$ type based on the following criteria. First, each cell had a relatively wide dendritic tree (300-400 $\mu \mathrm{m}$ diameter). Second, each cell stratified on the vitreal side of the nearby ON or OFF cholinergic (starburst) amacrine cell processes, similar to the stratification of ON and OFF Y/ $\alpha$-type cells in guinea pig and rabbit (Zhang et al., 2005; Margolis and Detwiler, 2007; Manookin et al., 2008; van Wyk et al., 2009; Estevez et al., 2012). Specifically, measured with two-photon imaging in vitro, the ON and OFF $\alpha$ cell dendritic trees stratified at $\sim 15$ and $\sim 27 \mu \mathrm{m}$ distal to the ganglion cell layer, respectively; whereas we have localized the ON and OFF starburst processes to $\sim 18$ and $\sim 30 \mu \mathrm{m}$ distal to the ganglion cell layer, respectively (Beier et al., 2013). Each recorded cell was confirmed to have the characteristic Y-type physiological property: a frequency-doubled response to a contrast-reversing grating composed of high spatial frequencies (Hochstein and Shapley, 1976; Demb et al., 1999) (see Figs. 5 and 7). Like $\mathrm{Y} / \alpha$-type cells in rabbit, cat, and primate, $\mathrm{Y} / \alpha$-type cells in mouse project to the lateral geniculate nucleus of the thalamus (Estevez et al., 2012; Beier et al., 2013). Below, we refer to these cells as Y-cells.

ROI selection and data analysis. ROIs used in the analysis of fluorescence data were defined as follows. For simultaneous fluorescence and current recordings, dye-filled arbors of the recorded cell were located in the IPL, and ROIs outlining the visible arbor in the imaged area were traced by hand using custom algorithms in MATLAB (The MathWorks). For recordings of fluorescence responses to vertical contrast-reversing gratings, the imaged area was divided along the horizontal axis into four nonoverlapping ROIs (Fig. 5B). For receptive field size measurements (Fig. $4 B, C)$, we used high zoom and either divided the imaged area $(25 \times$ $25 \mu \mathrm{m}$ ) into nine subregions (each $8.3 \times 8.3 \mu \mathrm{m}$ ) or averaged across the entire area. Responses in Figure 4, $B$ and $C$, were calculated as the peakto-trough amplitude during the ON and OFF stimulus phases. Specifically, we averaged three points near the peak of the response and subtracted three points near the trough of the response; for each imaged area, this response was further averaged across three periods per trial and across three trials. For the data presented in Figure $8 A$ (IPL stacks), we also used high zoom but divided the imaged area into $64 \times 64$ subregions. We then used Fourier analysis to calculate the modulation amplitude and phase of each subregion, set a threshold modulation amplitude $( \pm 0.05 \Delta \mathrm{F} / \mathrm{F})$ and used the relative phase of all above-threshold responses to average all ON-responding subregions into a single ON ROI and all OFF-responding subregions into a single OFF ROI (Fig. 8A, left and middle columns, respectively).

Spatial resolution of the two-photon imaging system. To estimate the spatial resolution of our imaging system, we recorded $z$-stacks of fluorescent beads ( $0.5 \mu \mathrm{m}$ diameter). The measured fluorescence profile could be fit by convolving the actual profile of the bead with a Gaussian point spread function (PSF; Fig. $2 G$ ). We fit one PSF in the radial plane, by analyzing the fluorescence change across the $x$-axis, at the $z$-level where the bead was best focused. We fit a second PSF in the axial plane by analyzing the fluorescence change through the center of the bead $(0.25 \times$ $0.25 \mu \mathrm{m}$ area in $x-y$ ) at subsequent $z$-positions. We describe the PSFs as the full-width-at-half-maximum of the fitted Gaussians (i.e., $2.35 \times \sigma$ of the fitted Gaussian): $0.48 \pm 0.02 \mu \mathrm{m}$ in the radial plane and $2.45 \pm 0.18$ $\mu \mathrm{m}$ in the axial plane (mean $\pm \mathrm{SD} ; n=6$ beads; Fig. $2 G$ ). These values are slightly larger than those measured previously (Dong et al., 2003), which can be explained primarily by the lower NA of our objective lens. The PSF in the axial plane suggests that $2 \mu \mathrm{m}$ spacing is reasonable for capturing stacks of fluorescence images, as in Figure 8.

Scan durations and photoreceptor activation by the scan laser. The laser scanned for 5-8 s to record the stimulus-evoked fluorescence response and then was switched off for $4-5 \mathrm{~s}$ between stimuli, to minimize bleaching. The scan laser apparently adds effective photoreceptor stimulation at a level that approximates the steady (always on) background illumination of $\sim 10^{4} \mathrm{R}^{\star} /$ cone/s, similar to previously reported values $(\sim 1-2.4 \times$ $10^{4} \mathrm{R}^{\star} /$ cone/s) (Euler et al., 2009; Baden et al., 2013). Thus, laser onset at the start of each trial evoked a light response from ON bipolar cells (e.g.,
Figs. $4 A$ and $7 D$ ). Because OFF bipolar cells are largely rectified at $\sim 10^{4}$ $\mathrm{R}^{\star} /$ cone/s, onset of the scan laser did not always cause a detectable decrease in glutamate release. To ensure stable light responses from ON and OFF cells, in most measurements stimulus onset was delayed by $1.5 \mathrm{~s}$ with respect to scan onset and the first $1.5 \mathrm{~s}$ was excluded from analysis.

Model fitting. We used a difference-of-Gaussians, center-surround model to fit the iGluSnFR responses to spots of increasing size (Fig. $4 B$ ) as follows:

$$
\begin{aligned}
R(r)=k_{\text {center }}(1-\exp [ & \left.-r^{2} /\left(2 \sigma_{\text {center }}^{2}\right)\right] \\
& -k_{\text {surround }}\left(1-\exp \left[-r^{2} /\left(2 \sigma_{\text {surround }}{ }^{2}\right)\right]\right),
\end{aligned}
$$

where $R$ is the fluorescence response (peak-to-trough amplitude), $k_{c e n t e r}$ and $k_{\text {surround }}$ are the peak amplitudes of the center and surround; $\sigma_{\text {center }}$ and $\sigma_{\text {surround }}$ are the SDs of the center and surround; and $r$ is spot radius (Rodieck, 1965). For this experiment, we divided the imaged $25 \times 25 \mu \mathrm{m}$ area into nine $8.3 \times 8.3 \mu \mathrm{m}$ subregions. We chose the subregion with the largest response, assuming this was best aligned to the stimulus center. Close alignment between the stimulus and the imaged region is further demonstrated by experiments where small spots were positioned at multiple offsets; the optimal response was at the expected position, centered on the imaged area (Fig. 4D). Model fitting was performed as described previously (Demb et al., 2001b). Fitting of the OFF responses in Figure $4 B$ was well constrained, whereas fitting of the ON responses was not well constrained. In particular, for ON responses the peak amplitudes of the fitted center and surround amplitudes were more than an order of magnitude larger than the maximum measured response. We therefore applied a constraint where the maximum fitted center response could be no larger than twice the maximum recorded response $(\sim 0.4 \Delta \mathrm{F} / \mathrm{F})$. This seemed reasonable, given that responses rarely exceeded 1.0 $\Delta \mathrm{F} / \mathrm{F}$, and given that when using this constraint the fitted curves for both $\mathrm{ON}$ and OFF responses changed negligibly by eye.

Statistical methods. We report mean \pm SEM throughout, unless noted otherwise. When a single recording generated data for multiple ROIs (e.g., for the data presented in Fig. 6), we used the number of recordings and not the (larger) number of ROIs as $n$ for calculating the SE and the degrees of freedom $(n-1)$ for corresponding statistical tests. Significance tests comparing differences between $\mathrm{ON}$ and OFF synapses (e.g., offset/amplitude comparison of Fig. 6; rectification and transience comparison of Fig. 7) were calculated with a Wilcoxon rank sum test (ranksum function in MATLAB, (The MathWorks).

\section{Results}

\section{Imaging glutamate release in the intact retina}

Our study used a recently developed sensor for synaptically released glutamate: intensity-based glutamate sensing fluorescent reporter (iGluSnFR) (Marvin et al., 2013). iGluSnFR comprises a circularly permuted GFP linked to a bacterial periplasmic glutamate/aspartate-binding protein (Escherichia coli GltI). Control experiments have demonstrated iGluSnFR's specificity for detecting glutamate in neural tissues, including the retina (Marvin et al., 2013). Here, we expressed iGluSnFR in the adult mouse retina through in vivo intraocular injection with adenoassociated virus under control of the human synapsin-1 promoter (AAV2/1-hSynapsin-iGluSnFR). Two weeks after transduction, a dense population of ganglion and amacrine cells expressed iGluSnFR in their membranes (Fig. 2A). iGluSnFR outlined somas in both ganglion cell and inner nuclear layers (INL) and dendrites throughout the inner plexiform layer (IPL). We projected light patterns onto the photoreceptors of the retina in vitro and recorded fluorescence responses in the IPL using a twophoton microscope (Fig. 2B). Visual stimuli were generated with a customized video projector that delivered UV light $(395 \mathrm{~nm}$ peak wavelength) at an intensity that evokes $\sim 10^{4} \mathrm{R}^{\star} / \mathrm{s}$ in both rods and cones (see Materials and Methods). Whole-cell recordings from a retina with functioning rods but not cones 


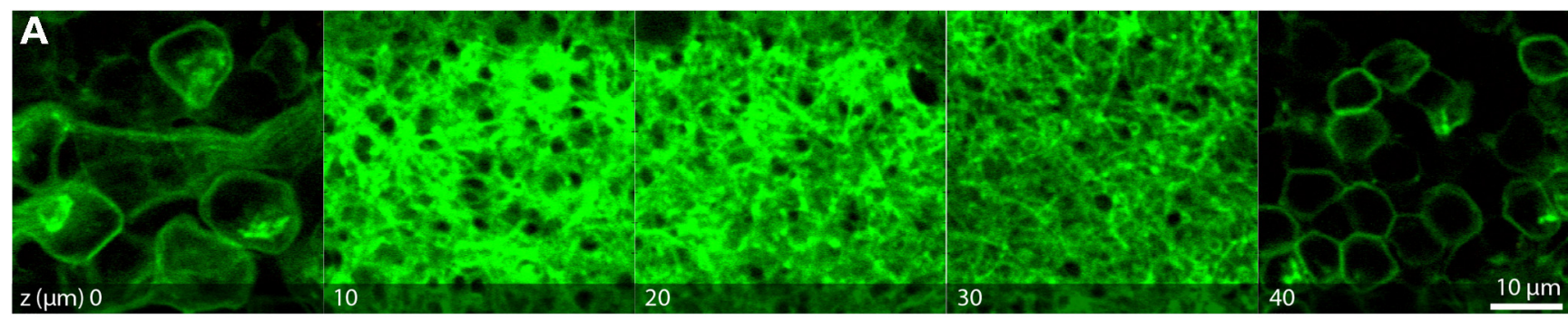

B
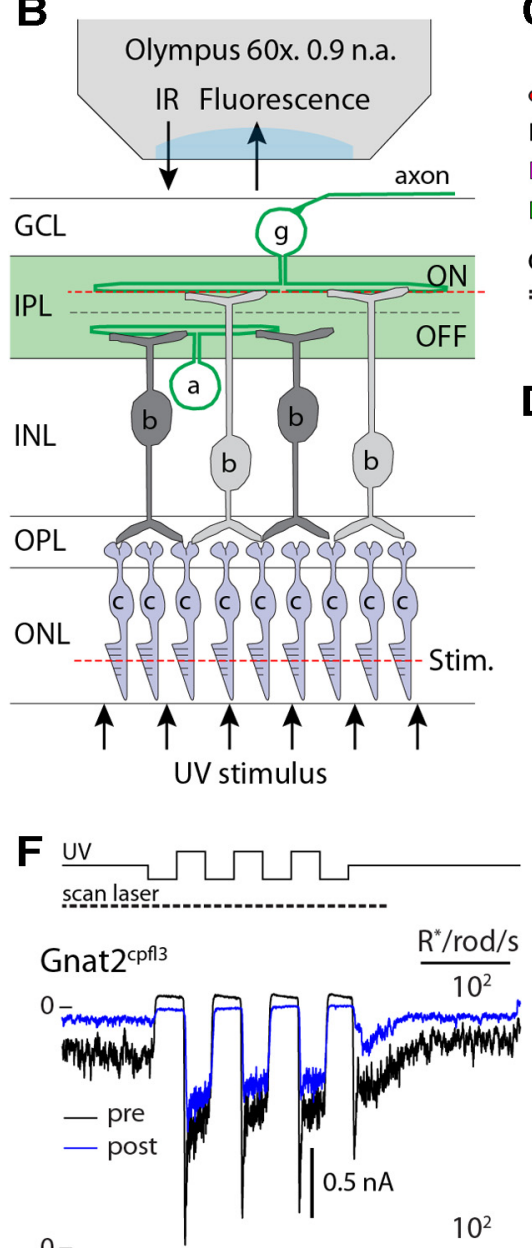

$0-$

$10^{2}$

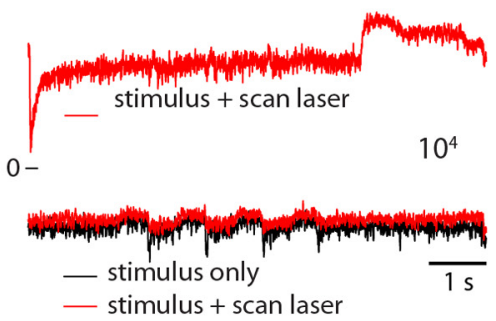

C

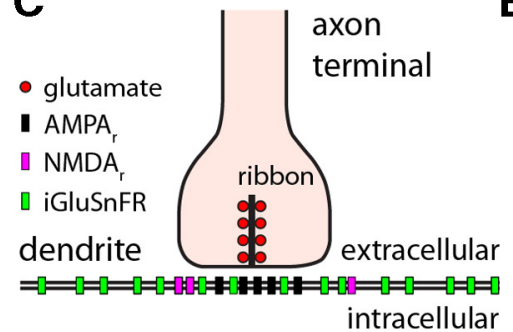

D
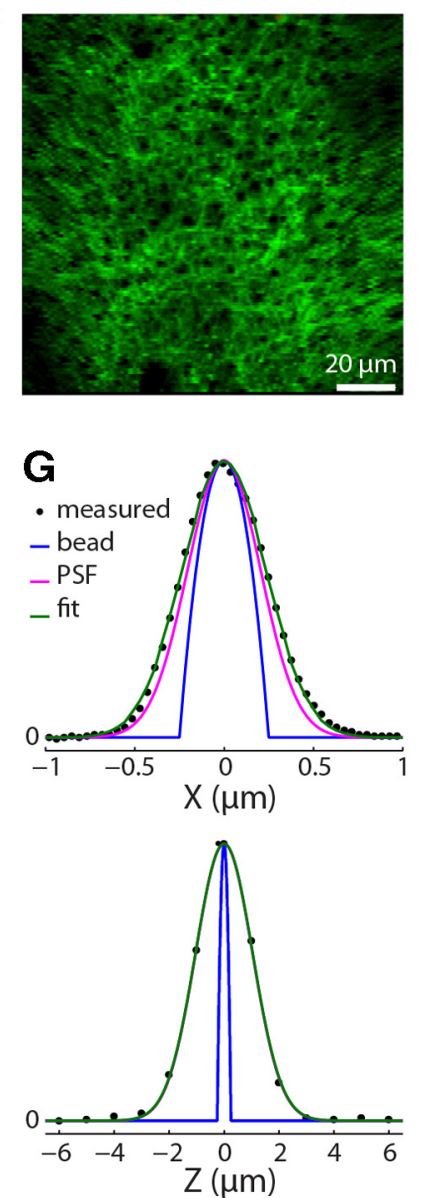

E
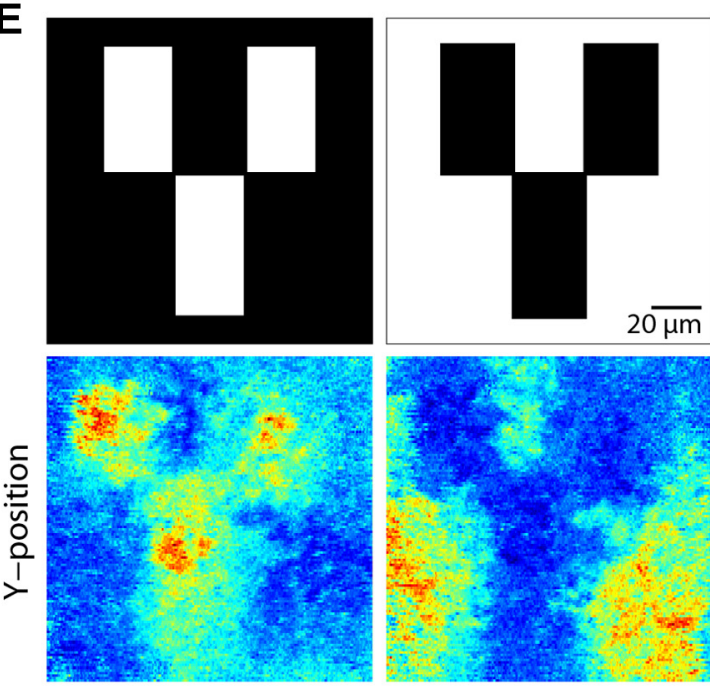

$\mathrm{X}$-position

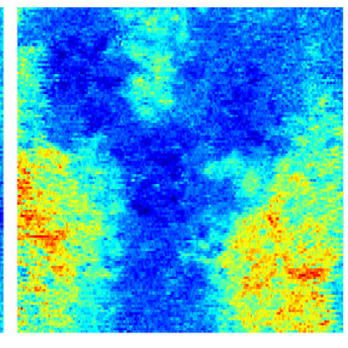

$\begin{array}{llllll}-0.4 & -0.2 & 0 & 0.2 & 0.4 & 0.6\end{array}$

Fluorescence $(\Delta F / F)$
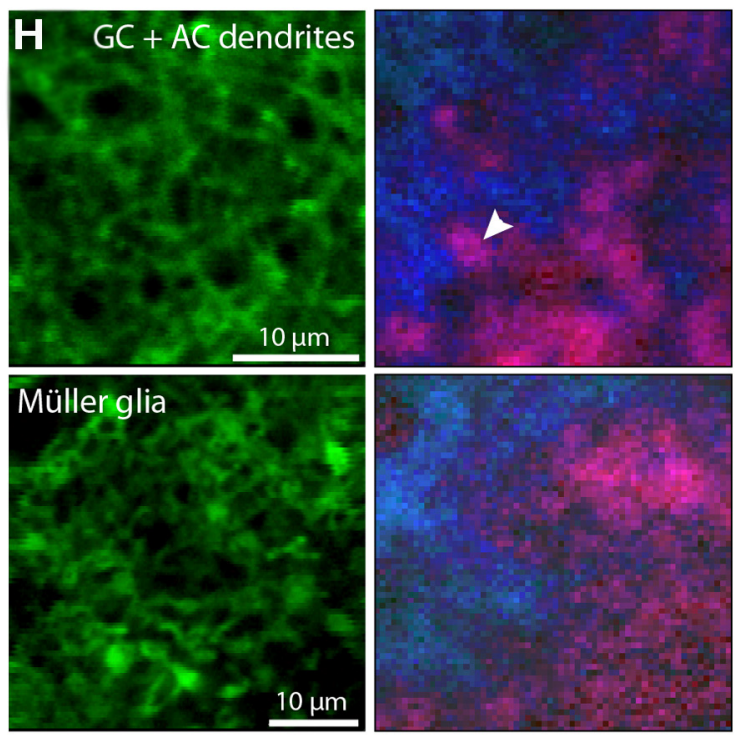

Figure 2. Imaging light-evoked glutamate release in the whole-mount retina. A, Two-photon fluorescence images of whole-mount mouse retina, in vitro. Transduction of adult retinas with AAV2/1-hSynapsin-iGluSnFR caused iGluSnFR expression in ganglion and amacrine cell membranes. $z=0 \mu \mathrm{m}$ was the image plane that hemisected the ganglion cell somas; $z$ increases toward the INL $(z=40 \mu \mathrm{m})$. B, Retinas were recorded on an upright microscope. Patterned light stimuli (peak wavelength $395 \mathrm{~nm}, 10^{4} \mathrm{R} / \mathrm{s}$ for both rods and cones) were projected onto the photoreceptors (c) through the condenser lens. Stimulus-evoked release of glutamate from bipolar cells (b) was measured with two-photon fluorescence imaging of iGluSnFR-expressing amacrine cell (a) and ganglion cell ( $\mathrm{g}$; ON-type shown here) dendrites in the IPL. Red dashed line indicates the focal plane shown in $\mathbf{D}$. C, Our conceptual model assumes diffuse expression of iGluSnFR throughout the cell membrane. iGluSnFR is expressed sufficiently near to synapses to report glutamate release. $D$, Two-photon fluorescence image of iGluSnFR-expressing dendrites of ganglion cells and amacrine cells in the IPL, $21 \mathrm{~d}$ after injection (whole-mount retina). $\boldsymbol{E}$, A patterned light stimulus ( $1 \mathrm{~Hz}$ contrast-reversing " $\mathrm{Y}^{\text {") }}$ ) evoked a matching fluorescence response (bottom: heat map, average of 12 reversals, same area as shown in $\boldsymbol{D}) . \boldsymbol{F}, 0 \mathrm{~N} \alpha$ cell excitatory current $\left(\mathrm{V}_{\text {hold }}=\mathrm{E}_{\mathrm{Cl}}\right)$ measured in a retina lacking cone function (Gnat2 ${ }^{\mathrm{cffl}}$ ). The cell responded strongly to a $1 \mathrm{~Hz}$ contrast-reversing spot (100\% contrast; $400 \mu \mathrm{m}$ diameter, solid line at top) at a $\operatorname{dim}\left(\sim 10^{2} \mathrm{R} / \mathrm{rod} / \mathrm{s}\right.$ ) mean level ("pre" recording). The cell responded to the scan laser (dashed line at top) but was saturated during the subsequent spot modulation. At a brighter mean $\left(10^{4} \mathrm{R}^{*} / \mathrm{rod} / \mathrm{s}\right)$, the response to the scan laser was absent and the stimulus-evoked response modulation was minimal. Upon return to the dim mean, the response could again be measured ("post" recording), demonstrating that the laser did not irreversibly bleach the rods. G, PSF measurements of the microscope. A bead (0.5 $\mu \mathrm{m}$ diameter) embedded in $1 \%$ agarose was imaged in the radial $(x-y)$ and axial ( $z$ ) planes. The bead profile (blue line) was convolved with a Gaussian (red line) to fit (Figure legend continues.) 
(Gnat $2^{\mathrm{cpfl} 3}$ ) showed only minimal responses at this light level and in the presence of the scan laser (see Materials and Methods; Fig. $2 F$ ). Thus, the responses described below from wild-type retina were mediated primarily by cones.

In the absence of ultrastructural data, our working model assumes that iGluSnFR is expressed throughout the cell membrane, including extrasynaptic locations on the dendrites (Fig. 2A,C). Such uniform labeling is consistent with the molecular structure of iGluSnFR, which displays the glutamate sensor extracellularly on a generic transmembrane helical domain (Marvin et al., 2013). For our purposes, the dendritic membranes in the IPL provided a scaffold on which iGluSnFR reported local glutamate release by the presynaptic bipolar cells, which were not labeled. To demonstrate the paradigm, we imaged the ON layer of the IPL (Fig. 2D) while projecting a contrast-reversing "Y" shape (Fig. 2E) onto the photoreceptors. Reversing luminance contrast of the "Y" evoked increases and decreases in iGluSnFR fluorescence relative to baseline $(\Delta \mathrm{F} / \mathrm{F}$; Fig. $2 E)$. The qualitative match between the visual stimulus and the spatial pattern of fluorescence changes shows that iGluSnFR readily resolves light-evoked glutamate release onto patches of dendrites at the scale of the bipolar cell axon terminals ( $\sim 20 \mu \mathrm{m}$ width) (Wässle et al., 2009).

We performed additional experiments to gauge the spatial resolution of the iGluSnFR signal. First, we measured the spatial resolution of our microscope (see Materials and Methods; Fig. $2 G)$. The point-spread function in the axial $(x-y)$ and radial $(z)$ dimensions could be described as Gaussians with widths of $\sim 0.5$ and $2.5 \mu \mathrm{m}$, respectively (full width at half-maximum). Second, we tested empirically our ability to measure distinct light responses at nearby release sites. Earlier experiments in acute hippocampal slices showed that iGluSnFR does not detect glutamate at regions $>1 \mu \mathrm{m}$ from the site of glutamate uncaging (Marvin et al., 2013). Here, we measured physiological release of glutamate at light ON and at light OFF near the middle of the IPL, where ON and OFF bipolar terminals intermingle. If synaptically released glutamate remained local ( $<1 \mu \mathrm{m}$ from the release site), then iGluSnFR would show distinct and spatially separated ON and OFF responses, whereas if glutamate spilled over a distance of several microns, then iGluSnFR would combine release from nearby $\mathrm{ON}$ and OFF terminals, resulting in ON/OFF responses at dendritic locations near the ON/OFF border. We found that iGluSnFR responses on ganglion and amacrine cell dendrites were either ON- or OFF-type, confined to distinct regions that intermingled with little overlap (Fig. $2 H$ ). The same result was obtained with iGluSnFR expressed on Müller glial cells, where iGluSnFR reported glutamate spillover from the synaptic cleft onto glial membranes. Collectively, the above measurements demonstrate that iGluSnFR is sensitive enough to detect glutamate spillover. They also show that the extracellular spread of glutamate is sufficiently limited such that synaptic release events from distinct terminals can be resolved spatially and our optical system can accurately distinguish these adjacent, distinct signals.

\section{$\leftarrow$}

(Figure legend continued.) (green line) the measured responses (black points). For the axial dimension (bottom plot), the green and red lines overlap. $\boldsymbol{H}$, Two-photon fluorescence images (left) and color-coded fluorescence responses (right) obtained at the ON-OFF border in the central IPL. Color of each pixel represents the sum of the response amplitude to light ON (blue) and the response to light OFF (magenta) relative to baseline. Separation of pixels into intermingled blue and magenta regions (arrowhead) demonstrates that local responses were predominantly $\mathrm{ON}$ - or OFF-type; dendritic regions with substantial ON-OFF release (purple) were lacking. iGluSnFR expressed in ganglion cells and amacrine cells (top; hSynapsin promoter), and iGluSnFR expressed in Müller glia (bottom; GFAP promoter) gave similar results.

\section{iGluSnFR fluorescence is proportional to synaptic release in the physiological range}

To compare quantitative fluorescence measurements with established measurements of excitatory synaptic transmission, we simultaneously recorded iGluSnFR responses and excitatory currents in a Y-cell using whole-cell patch-clamp. We focused on the recorded cell's dendrites, visualized with a red fluorescent dye delivered through the patch pipette (Alexa-568; Fig. $3 A$ ), and recorded iGluSnFR fluorescence during stimulation with a small spot (150 $\mu \mathrm{m}$ diameter) centered on the imaged area. Contrastreversal of the spot (dark $\longleftrightarrow$ light) evoked iGluSnFR fluorescence responses with a time course similar to the EPSCs and negligible delay (Fig. $3 B, C$ ), consistent with the sensor's rapid response kinetics. Here and below, we report the nominal contrast of the stimulus. However, the scan laser added a constant luminance background, reducing the effective contrast of the stimulus. Despite this laser stimulation, we measured detectable fluorescence and current responses to contrasts as low as $10 \%$ (Fig. 3C). Response amplitudes increased with increasing contrast (Fig. $3 B-D$ ) and the relationship between the two measures was approximately linear (Fig. $3 E ; n=4$ cells). Thus, iGluSnFR adequately captured the physiological range of glutamate release evoked by light stimulation. We conclude that iGluSnFR permits direct, real-time measurement of synaptically released glutamate in the IPL of the intact, whole-mount retina.

\section{Characterizing bipolar cell spatial receptive fields at the level of glutamate release sites}

A characteristic property of the nonlinear subunits is that they can resolve high spatial frequencies (Hochstein and Shapley, 1976; Demb et al., 1999). Therefore, to form the Y-cell's nonlinear subunits, the receptive fields of bipolar cells must be narrow. Cone bipolar cell receptive fields in mammalian retina have been measured in only a few cases, including light-adapted recordings in primate (Dacey et al., 2000) and dark-adapted recordings in mouse retinal slice (Berntson and Taylor, 2000), or a wholemount preparation at a 10 -fold lower light level (Schwartz et al., 2012). Here, we measured the receptive fields of bipolar cells in small patches of amacrine or ganglion cell dendrites $(8.3 \times 8.3$ $\mu \mathrm{m}$ subregion of a $25 \times 25 \mu \mathrm{m}$ area; see Materials and Methods), which reflect signaling through one or a small number of axon terminals. By imaging iGluSnFR responses, we recently made the first measurements of bipolar receptive fields at the level of synaptic release in whole-mount tissue using drifting gratings (Marvin et al., 2013) presented with visible light (i.e., not UV) and recorded at an arbitrary level of the IPL. Here, we measured iGluSnFR responses to spot stimuli using UV light for improved S-opsin stimulation (see Materials and Methods), and focused specifically at the levels where ON and OFF Y-cells stratify (Fig. 4).

iGluSnFR responses in both ON- and OFF layers of the IPL showed a center-surround receptive field organization (Fig. 4A). The response amplitude increased for spot diameters up to $\sim 150$ $\mu \mathrm{m}$ and decreased sharply for diameters $>200 \mu \mathrm{m}$ (Fig. 4B). The largest spots typically evoked surround-mediated $\mathrm{ON}$ responses in the OFF layer (Fig. 4A, B). The responses to different spot sizes were fit with a difference-of-Gaussians center-surround receptive field model (see Materials and Methods). The center width ( $2 \sigma_{\text {center }}$ of fitted Gaussian) was $81 \mu \mathrm{m}$ for ON responses and 66 $\mu \mathrm{m}$ for OFF responses (Fig. $4 B$ ). These values are larger than previous recordings of mouse bipolar cells $(44 \mu \mathrm{m})$ (Schwartz et al., 2012) but similar to measurements from primate diffuse bipolar cells (65 $\mu \mathrm{m}$ for $2 \sigma$ width; Dacey et al., 2000). The strong 

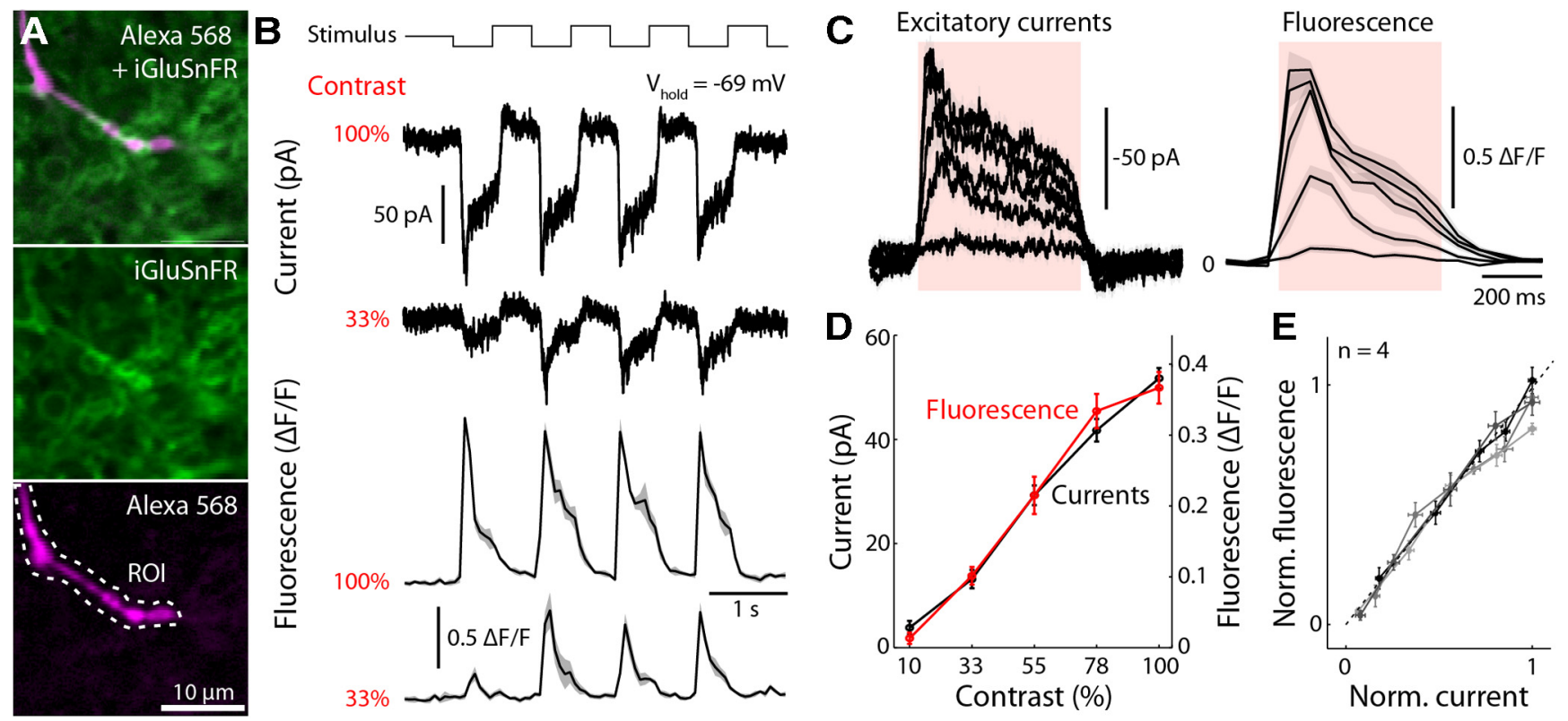

Figure 3. iGluSnFR fluorescence parallels excitatory current across contrast levels. $A$, Two-photon fluorescence images of the dendritic arbor of an iGluSnFR-expressing 0 FF Y-type ganglion cell, targeted for whole-cell recording. The cell was filled with a red fluorescent dye (Alexa-568) through the patch pipette. iGluSnFR fluorescence intensity was averaged across the ROl indicated by the dashed outline. $\boldsymbol{B}$, Simultaneously recorded excitatory currents (top) and fluorescence responses (bottom) evoked with contrast stimulation (150- $\mu$ m-diameter spot) at two contrast levels (same cell as shown in $\boldsymbol{A}$ ). The fluorescence response is reported as fractional change in fluorescence intensity compared with the baseline intensity $(\Delta \mathrm{F} / \mathrm{F})$. Solid line and shaded region represent mean $\pm \mathrm{SEM}$ of four repeats at each contrast level. C, Average excitatory current (left, shown inverted for comparison) and fluorescence response (right) to spots at five contrasts from 10\% to 100\%. Each curve shows the average response during the dark phase of the stimulus (mean of 12 periods). $\boldsymbol{D}$, Contrast response functions based on the excitatory current (black) and fluorescence response (red) integrated over the duration of the response $(\boldsymbol{C}$, pink area). Error bars indicate SEM across trials. $E$, Scatter plot of excitatory current and fluorescence response amplitude from $10 \%$ to $100 \%$ contrast ( $n=4$ cells, indicated by different colors). Responses were normalized by fitting a line to the data for each cell and scaling currents and fluorescence responses to the current amplitude of the fit at $100 \%$ contrast. Error bars indicate SEM across trials.

surround responses are also consistent with the primate recordings. Simultaneous fluorescence and ganglion cell current recordings showed that the optimal spot size for a bipolar cell is approximately twofold smaller than the optimal spot size for a Y-cell (Fig. 4C).

The strong surround suppression measured in the bipolar cell release implies that a spot that is optimal for the ganglion cell ( 400 $\mu \mathrm{m}$ diameter) evokes weak responses from bipolar cells near the spot's center and stronger responses from bipolar cells near the spot's edge. Fluorescence measurements confirmed this (Fig. 4D): the response amplitude of OFF bipolar cells under the center of a $400-\mu \mathrm{m}$-diameter spot was $\sim 85 \%$ reduced compared with the response of bipolar cells near the edge $(0.04 \pm 0.06$ vs $0.30 \pm 0.08$ $\Delta \mathrm{F} / \mathrm{F}, p<0.002$; Fig. $4 D-F)$; the reduction for ON bipolar cells was $\sim 50 \%(0.21 \pm 0.08$ vs $0.42 \pm 0.14 \Delta \mathrm{F} / \mathrm{F}, p<0.035$; Fig. $4 F)$.

\section{The spatial subunit nonlinearity occurs after contrast} integration by the bipolar cell

We next tested whether the subunit nonlinearity occurs before or after spatial integration by the bipolar cell. Recordings in salamander retina suggested that bipolar cells integrate linearly (Baccus et al., 2008) but did not explicitly test for response nulling (Fig. 1). Furthermore, nonlinearities presynaptic to cone bipolar cells have been demonstrated in the mammalian retina, which might contribute to nonlinear release at the bipolar terminal (Gaudiano, 1992; Schneeweis and Schnapf, 1999; Hennig et al., 2002; Jackman et al., 2009). We made whole-cell recordings from either ON or OFF Y- cells while simultaneously recording iGluSnFR fluorescence in small $(65 \times 65 \mu \mathrm{m})$ regions that included the recorded ganglion cell's dendrites (Fig. 5). The retina was stimulated with a contrastreversing grating within a $650-\mu \mathrm{m}$-diameter patch centered on the recorded cell. The grating was presented at several spatial phases within the patch. If the nonlinear computation occurs after the point of spatial integration by the bipolar cell, then glutamate release should modulate maximally at the stimulus frequency (F1 response) at one position (preferred phase) but be silenced at the null position, 90 degrees from preferred (Fig. 1B). Alternatively, if the nonlinear computation occurs before the point of spatial integration by the bipolar cell (i.e., at the level of the cones' synaptic output), then glutamate release would show a frequency-doubled response at the null phase (Hochstein and Shapley, 1976).

In response to a $2 \mathrm{~Hz}$ contrast-reversing grating, EPSCs in an ON-type Y-cell showed $4 \mathrm{~Hz}$ (frequency-doubled) modulation at all spatial phases (Fig. 5A). Phase independence of the frequency doubled response is a hallmark of the nonlinear subunits (Hochstein and Shapley, 1976). Simultaneously recorded iGluSnFR fluorescence responses averaged over small ROIs ( $10 \mu \mathrm{m}$ wide; Fig. $5 B$ ) showed $2 \mathrm{~Hz}$ modulations at most spatial phases as well as a clear null phase with no modulation (Fig. $5 C$ ). The spatial phase that evoked the null response (Fig. 5 C, arrows) differed systematically for neighboring ROIs, shifting in accordance with ROI position (Fig. $5 D$ ). The same pattern was observed for all recorded cells and ROIs ( $n=5$ ON cells, 28 ROIs; 4 OFF cells, 24 ROIs). These results suggest that nonlinearities occur at the bipolar cell output, after the point of spatial integration.

\section{Release from ON synapses is suppressed by a} TPMPA-sensitive inhibitory surround

There was a distinct difference between null-phase responses recorded at ON Y-cell dendrites (ON synapses) compared with the same responses recorded at OFF Y-cell dendrites (OFF synapses). For OFF synapses, a null-phase grating evoked no detectable change in fluorescence, but for ON syn- 


\section{A Spot diameter $(\mu \mathrm{m})$}
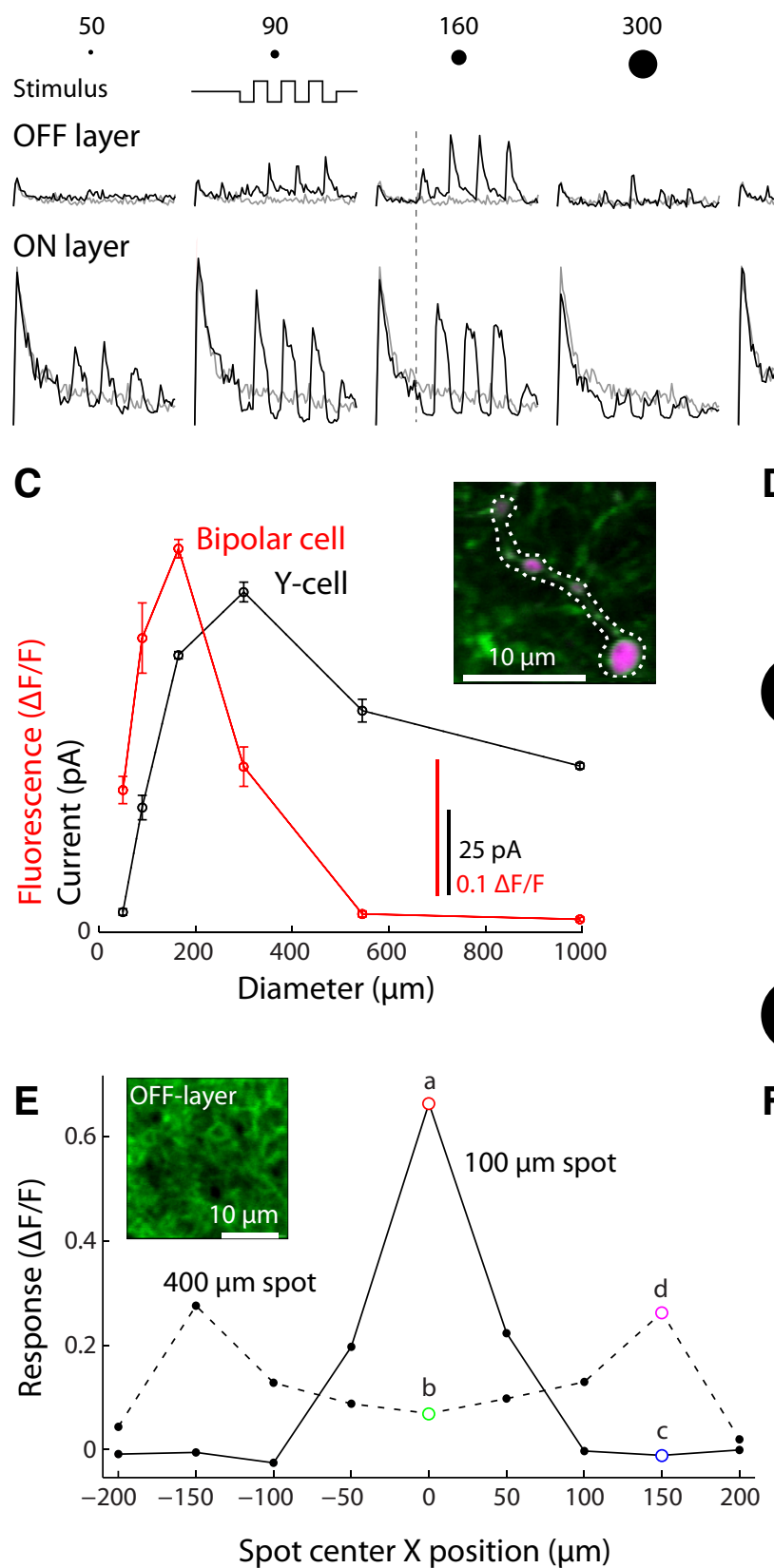

D
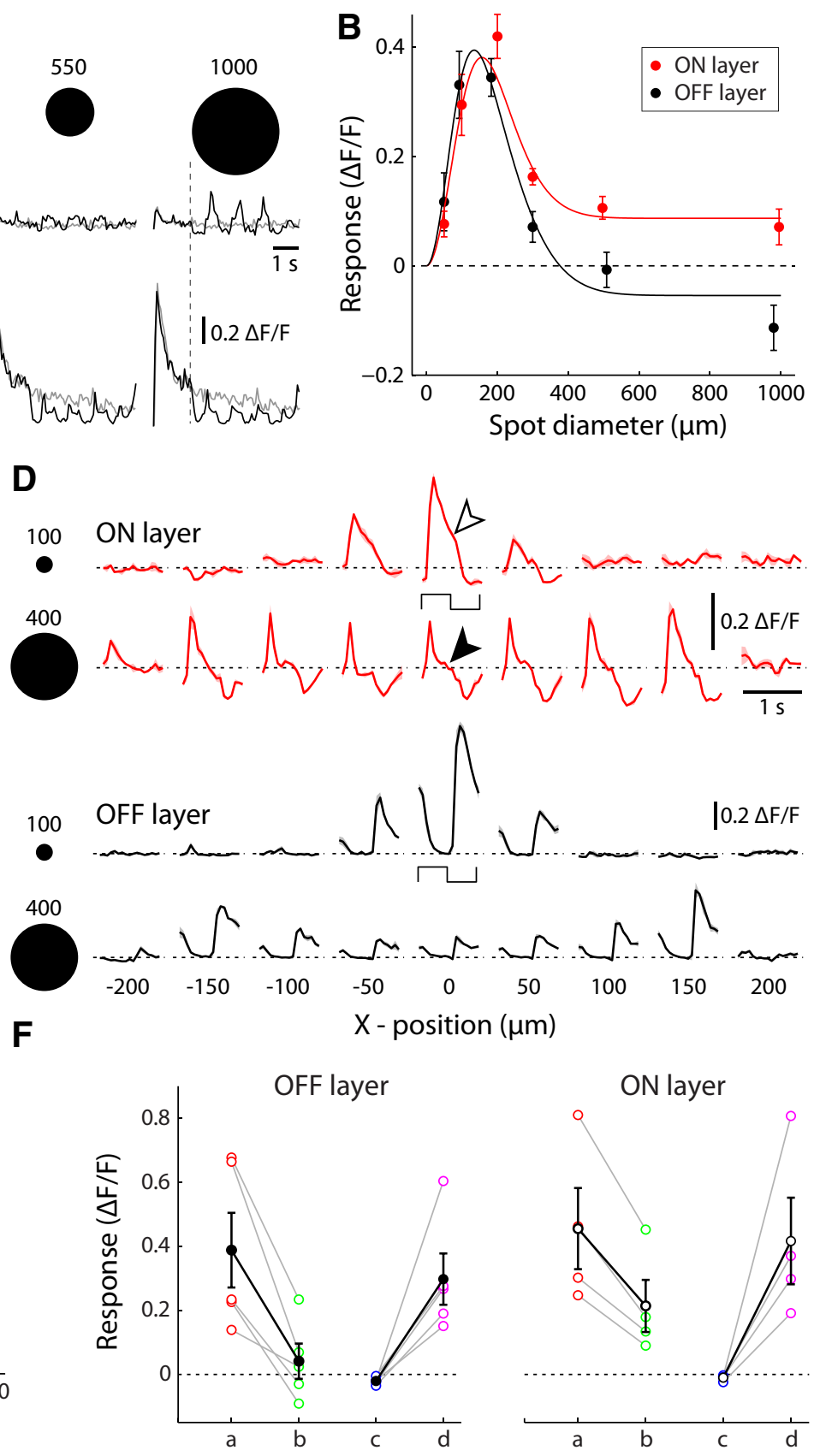

Figure 4. Retinal bipolar cells under light-adapted conditions have strong inhibitory surrounds. $A$, Fluorescence responses to contrast-reversing spots of increasing diameter (top). Responses were recorded from iGluSnFR-expressing dendrites in the OFF and ON layers of the IPL ( 30 and $16 \mu \mathrm{m}$, respectively, distal to the ganglion cell layer). Traces represent the average fluorescence change in a $25 \mu \mathrm{m} \times 25 \mu \mathrm{m}$ area under the center of the spot. Responses in the OFF layer often changed from $0 \mathrm{FF}$ to $0 \mathrm{~N}$ responses for the largest spot size (response timing indicated with vertical dashed lines). Gray trace represents fluorescence signal during blank trials, when no spot was presented. $\boldsymbol{B}$, Average size tuning functions for ON and OFFbipolar cells ( $0 \mathrm{~N}: z=16 \mu \mathrm{m}, n=14 ; 0 \mathrm{FF}: z=30 \mu \mathrm{m}, n=13)$. Data points indicate fluorescence change in the maximally responding $8.3 \times 8.3 \mu \mathrm{m}$ subregion in each of the imaged areas, including those shown in $A$; error bars represent SEM across subregions. Curves represent peak-to-trough modulation amplitude of the recorded response (see Materials and Methods). A negative amplitude in response to large spots (OFF layer) indicates a fluorescence increase during the light phase of the stimulus ( $0 \mathrm{~N}$ response; as in $A$ ). The fitted lines indicate difference-of-Gaussians center-surround models (see Materials and Methods). The parameters for $0 \mathrm{~N}$ responses were as follows: $k_{\text {centerr }} 0.84 \Delta F / F ; k_{\text {surround }}, 0.75 \Delta F / F ; \sigma_{\text {center }}$ $40.6 \mu \mathrm{m} ; \sigma_{\text {surround }}, 73.2 \mu \mathrm{m}$. The parameters for $0 \mathrm{FF}$ responses were as follows: $k_{\text {center }} 0.69 \Delta \mathrm{F} / \mathrm{F} ; k_{\text {surround }}, 0.75 \Delta \mathrm{F} / \mathrm{F} ; \sigma_{\text {center }}, 32.9 \mu \mathrm{m} ; \sigma_{\text {surround }}, 82.4 \mu \mathrm{m}$. $C$, Simultaneously recorded size-tuning function of bipolar cells (red) and a postsynaptic ganglion cell (black). Bipolar cell tuning function reflects size tuning at the level of glutamate release; ganglion cell function shows tuning at the level of postsynaptic excitatory current. Curves represent peak-to-trough modulation amplitude of the response. Error bars indicate SEM across repeated trials. Inset, Two-photon fluorescence image of iGluSnFR expressing dendrites (green) and the dendrite of the recorded ganglion cell (red). D. Responses of ON (top) and OFF (bottom) bipolar cells to a small and a large spot stimulus presented at different distances from the bipolar cells' receptive field center. The $0 \mathrm{~N}$ bipolar cell response was more transient for a centered large spot compared with a centered small spot (solid and open arrowheads, respectively). Stimulus time course shown below centered stimulus traces. $\boldsymbol{E}$, Response amplitudes of the OFF layer data shown in $\boldsymbol{D}$.F, Quantification of the response to centered and peripheral, small and large spots (ON $n=4 ; 0$ FF $n=5$ ):a, response amplitude for a small, centered spot; b, response amplitude for a large, centered spot; c, response amplitude for a small, peripheral spot; d, response amplitude for a large, peripheral spot. See $\boldsymbol{E}$ for reference. Error bars indicate SEM across ROIs $(25 \mu \mathrm{m} \times 25 \mu \mathrm{m}$ area $)$. 

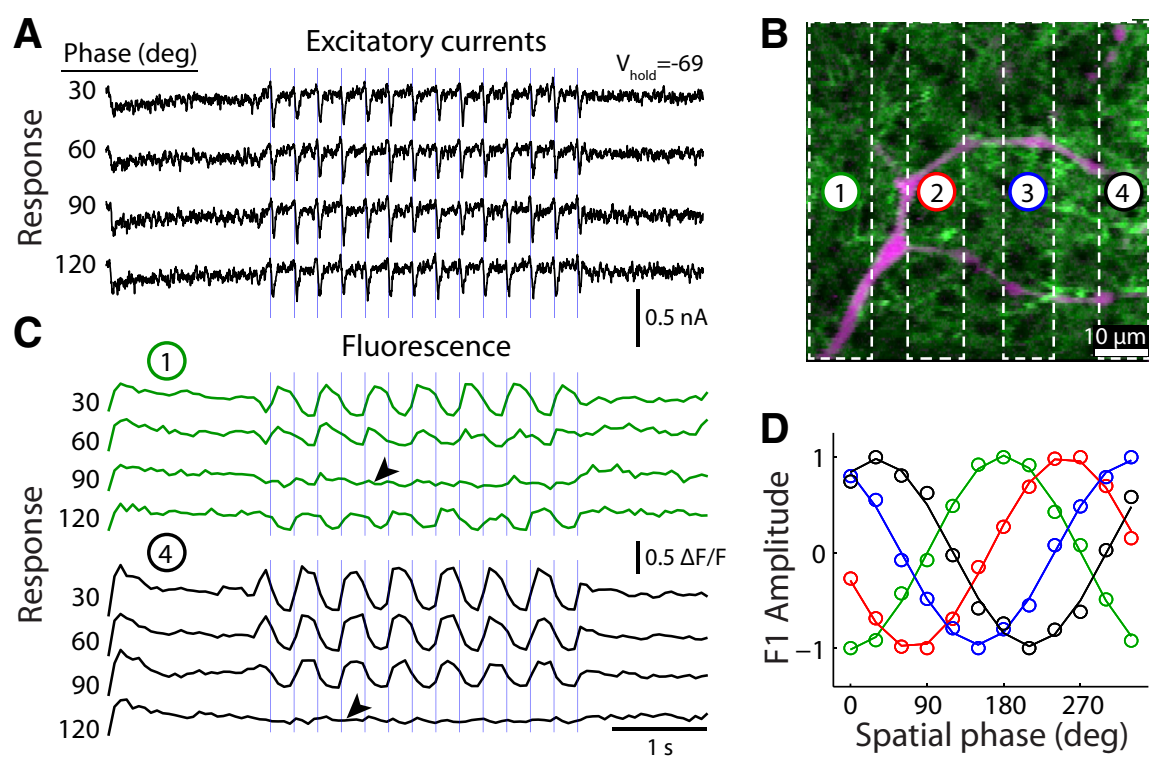

Figure 5. Bipolar cell glutamate release in response to contrast-reversing gratings demonstrates linear integration by bipolar cells. $\boldsymbol{A}$, Excitatory currents recorded in whole-cell patch-clamp from an iGluSnFR-expressing neuron. Responses show a transient inward current at each contrast reversal (blue lines; F2 response). The response is independent of spatial phase (spatial frequency, 10 cycles $/ \mathrm{mm}$ ). Shaded region represents SEM across trials. $\boldsymbol{B}$, Two-photon fluorescence image of iGluSnFR-expressing dendrites (green) and an 0N-type $\mathrm{Y}$-cell filled with a red dye (Alexa-568; same cell as $\boldsymbol{A}$ ). Dashed lines indicate ROls used in the analysis. $\boldsymbol{C}$, Fluorescence responses recorded simultaneously with the current recording shown in $\boldsymbol{A}$ (ROls indicated in $\boldsymbol{B}$ ). Each local region responds at the stimulus frequency (F1 response). Each region shows a null phase (arrowhead), as predicted by the model with linear integration by the bipolar cells before the stage of glutamate release (Fig. 1). D, Normalized response amplitude for the data shown in $\boldsymbol{B}, \boldsymbol{C}$. Response sign was either positive for initially rising responses or negative for initially falling responses. Each response is plotted twice (e.g., the response at 180 degrees is the inverse of the response at 0 degrees).

apses, the null-phase grating reduced fluorescence $(0.12 \pm$ $0.03 \Delta \mathrm{F} / \mathrm{F}$; mean $\pm \mathrm{SEM}, n=4$ recordings, 16 ROIs). This reduction ("offset") suggests active suppression of ongoing glutamate release from ON bipolar terminals (Fig. 6A, $B$ ).

To test whether $\mathrm{ON}$ synapses were actively suppressed through lateral inhibition, we compared responses to a contrastreversing, high spatial frequency grating presented in either a small or large aperture (150 and $1000 \mu \mathrm{m}$ diameter; Fig. $6 C$ ). The large stimulus lowered the response offset from $0.01 \pm 0.01$ to $-0.05 \pm 0.01 \Delta \mathrm{F} / \mathrm{F}(p<0.001)$ and the response amplitude from $0.13 \pm 0.02$ to $0.10 \pm 0.01 \Delta \mathrm{F} / \mathrm{F}(n=22$ areas, 89 ROIs, $p<0.005$; Fig. 6D). Response offset was reduced both at the preferred and null phases, indicating that suppression was independent of strong response modulation. The fact that this inhibition could be activated with a high spatial frequency stimulus further implicated an amacrine cell mechanism and not a horizontal cell mechanism because, through electrical coupling, horizontal cells cannot resolve high spatial frequencies (Shelley et al., 2006; Zaghloul et al., 2007; Baccus et al., 2008). The inhibitory mechanism acted over hundreds of microns, suggesting it was mediated by wide-field amacrine cells.

Most wide-field amacrine cells are GABAergic (Pourcho and Goebel, 1983; Vaney, 1990; Flores-Herr et al., 2001). We tested whether the surround inhibition acted through $\mathrm{GABA}_{\mathrm{c}}$ receptors, which are expressed on the axon terminals of ON bipolar cells (Euler and Wässle, 1998; Shields et al., 2000; Eggers et al., 2007). The $\mathrm{GABA}_{\mathrm{C}}$ antagonist TPMPA $(50 \mu \mathrm{M})$ blocked the suppression evoked by the large stimulus, evidenced by an increase in response offset of $0.04 \pm 0.01 \Delta \mathrm{F} / \mathrm{F}(n=7$ areas, 29 ROIs, $p<0.01$; Fig. 6C,E). TPMPA did not affect the response offset for the small stimulus $(p>0.5)$. TPMPA had variable effects on the response amplitude of individual ROIs, with no significant effect on average (both stimuli $p>0.5$; Fig. $6 E$ ). These measurements show that a TPMPA-sensitive inhibitory surround controls basal synaptic release from bipolar cells in the stratification layer of ON-type Y-cells.

\section{The nature of the nonlinearity of $\mathrm{ON}$ and OFF bipolar cell synapses differs}

To understand how glutamate release at $\mathrm{ON}$ and OFF synapses generates a frequency-doubled response, we made high-resolution measurements of the time course of light-evoked glutamate release with $2 \mathrm{kHz}$ line scans across iGluSnFR-expressing dendrites (Fig. $7 A, B)$. As before, a $2 \mathrm{~Hz}$ contrastreversing grating evoked a frequencydoubled response in Y-cell EPSCs, whereas local fluorescence responses modulated at the reversal frequency (Fig. $7 C, D)$. OFF synapses showed negligible ongoing release, with only increases above baseline, and responses were relatively transient (Fig. 7C). ON synapses showed substantial ongoing release, with modulations above and below baseline, and responses were relatively sustained (Fig. 7D).

We quantified the degree of rectification (i.e., the extent of response decrement below baseline) and the transience (Fig. 7 E, F). Rectification was measured by calculating how much the nonpreferred stimulus phase suppressed release relative to the baseline measured before and after contrast-modulation (Fig. $7 E$; rectification $=-d /(a-d))$. For ON synapses, $74 \pm 6 \%(n=$ 27 areas, 108 ROIs) of the response modulation occurred below the baseline, compared with $8 \pm 3 \%$ ( $n=14$ areas, 54 ROIs $)$ for OFF synapses. Thus, ON synapses were significantly less positively rectified than OFF synapses $(p<0.001$; Fig. $7 G)$. Next, we measured response transience, defined as the decrease in fluorescence during the preferred stimulus phase as a percentage of the total response modulation amplitude (transience $=(a-b) /(a-$ $d$ ) in Figure $7 E$ ). The decrease in fluorescence was $16 \pm 4 \%$ for ON synapses compared with $69 \pm 3 \%$ for OFF synapses. Thus, ON synapses were also significantly less transient than OFF synapses $(p<0.001$; Fig. $7 G)$.

Our data show that synaptic release from the bipolar cells that stratify at the level of the ON-type Y-cell dendrites is relatively linear (i.e., unrectified and sustained). How then can their combination generate a nonlinear response in the postsynaptic Y-cell? To answer this, we summed the recorded responses of two sets of bipolar cell synapses, each with receptive fields under the center of the bars so that they responded maximally to the contrastreversing stimulus, but in opposite temporal phase. Bipolar cells at intermediate spatial phases would have smaller response amplitudes that all fall into one of the two temporal phase groups already represented in the calculation (Fig. $7 \mathrm{H}$ ); these responses were omitted for simplicity. We used high-resolution iGluSnFR recordings from two OFF ROIs (Fig. $7 C$; one phase shifted to generate opposite-phase responses) to represent responses in the OFF layer and two ON ROIs that responded in opposite phase (Fig. 7D) to represent responses in the ON layer. We normalized the responses from the two populations to have equal modula- 

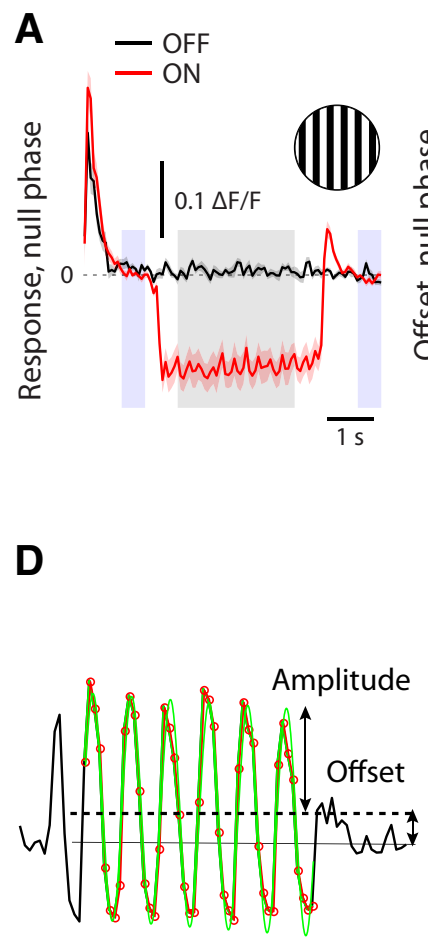
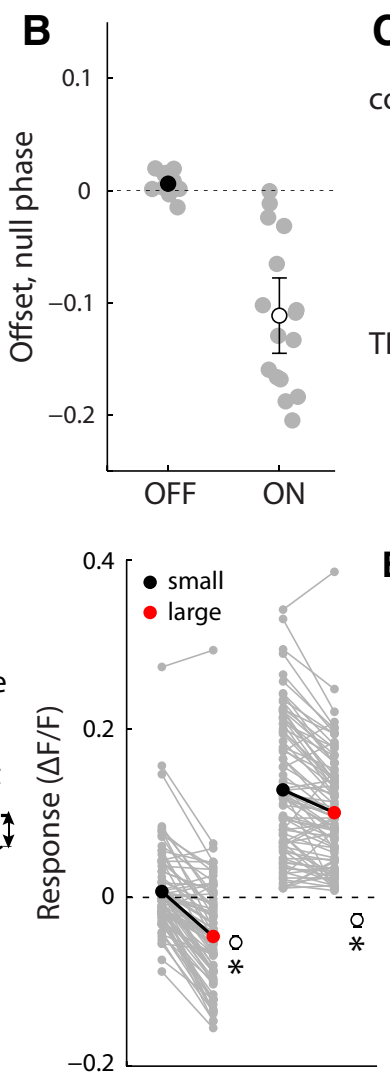

Offset Amplitude
C Preferred-phase ROI

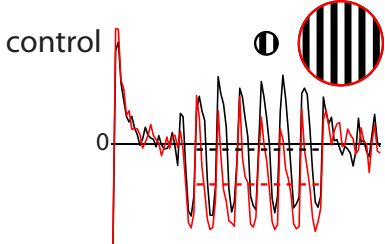

TPMPA

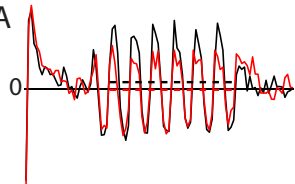

E

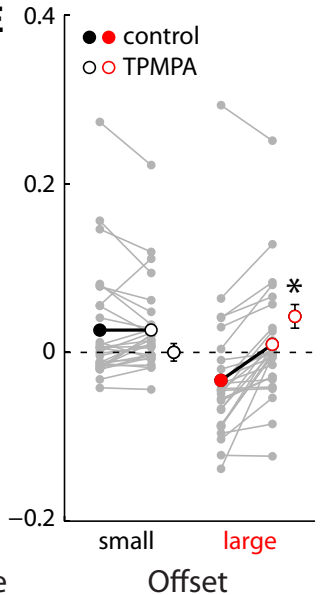

Null-phase ROI
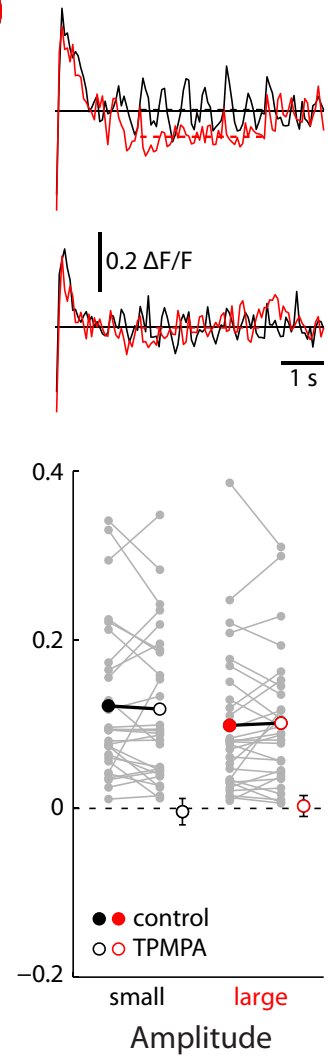

Figure 6. A TPMPA-sensitive surround suppresses $O N$ synapses during stimulation with high spatial frequencies. $A$, Fluorescence response during the null phase for glutamate release onto an $0 \mathrm{~N}$ Y-cell (red) and an OFF Y-cell (black); SEM shown in pink and gray, respectively. The contrast-reversing grating suppressed glutamate release in the ON layer, but not the OFF layer. $\boldsymbol{B}$, Quantification of the suppression of glutamate release in the $\mathrm{ON}$ - and $0 \mathrm{FF}$ layer during the null phase $(\mathrm{ON}, n=16 ; 0 \mathrm{FF}, n=12)$. Each point represents one ROI. Points indicate the average fluorescence change during contrast stimulation relative to baseline $(\boldsymbol{A}$, gray and blue regions, respectively). Summary points and error bars represent mean \pm SEM. $\boldsymbol{C}$, Fluorescence recordings from bipolar cell synapses in the $0 \mathrm{~N}$ Y-cell layer stimulated with contrast-reversing gratings in a small (150 $\mu \mathrm{m}$; black) and large (1000 $\mu \mathrm{m}$; red) aperture (top). The large stimulus caused TPMPA-sensitive suppression of release, both in the preferred and null phase. The null phase was approximate; there was a small residual response in some traces. $\boldsymbol{D}$, The response offset and modulation amplitude were computed with a sinusoidal fit (green line) to the data. Response offset and modulation amplitude for all recorded responses to small (black) and large (red) stimuli in control conditions ( $n=89 \mathrm{ROls}$ from 22 measurements). Data points next to each population indicate the mean difference \pm SEM for each condition; asterisks indicate significant changes. $\boldsymbol{E}$, Response offset (left) and modulation amplitude (right) for all recorded responses to small (black) and large (red) stimuli in control (solid) compared with TPMPA conditions (open symbols; $n=29$ ROls from 7 measurements). Summary points and error bars represent mean \pm SEM. Asterisks indicate significant changes.

tion amplitude and summed them to approximate integration by a postsynaptic OFF or ON Y-cell, respectively (Fig. 7C,D). Summed OFF responses generated a frequency-doubled signal, as expected from rectified, transient release. Importantly, summed ON responses also generated a frequency-doubled signal that was very similar to that of the OFF responses, despite the relatively less rectified and more sustained nature of release (Fig. $7 E-G)$. The main insight from this analysis is that relatively sustained glutamate release from bipolar cells can drive a nonlinear response in the postsynaptic ganglion cell. The explanation is that the relatively rapid onset of glutamate release combined with a relatively slower offset back to the baseline level generates a transient, frequency-doubled response (Fig. $7 H$ ).

\section{Nonlinear synaptic release is ubiquitous across the inner plexiform layer}

We asked whether the nonlinear properties of bipolar cell synapses are specific to those layers where Y-cells stratify their dendrites. We measured fluorescence responses to contrast modulation of small spots (150 $\mu \mathrm{m}$ diameter) while systematically imaging the IPL at $2 \mu \mathrm{m}$ increments from the ganglion cell layer to the INL ( $>20$ levels; Fig. $8 A$, left and center columns; $n=14 z$-stacks, see Materials and Methods for definition of ROIs). The response at each level $(\Delta \mathrm{F} / \mathrm{F})$ was quantified with measures of transience, and increase and decrease of release with respect to baseline (Fig. $8 B$ ). We also measured responses at the contrast modulation frequency (F1 response) and simulated the population response to a contrast-reversing grating, by combining the original spot responses with those shifted by a stimulus half-cycle (F2 response; Fig. 8A, right column).

These measurements showed several systematic differences between layers of the IPL. We readily resolved the expected division between ON- and OFF-type bipolar cell synapses (Fig. $8 A, C)$. At the ON/OFF boundary, we consistently observed a layer that contained both $\mathrm{ON}$ and OFF responses. Here, $\mathrm{ON}$ and OFF bipolar cells released glutamate onto intermingled, but nonoverlapping, ON- and OFF-regions, as described above (Fig. $2 \mathrm{H}$ ). Release in $\mathrm{ON}$ layers was generally less rectified than release in OFF layers (Fig. 8 B, C). Synaptic release (both ON and OFF) in layers near the center of the IPL was more transient than release in those layers closest to the IPL's borders (Fig. 8A). The relative 
A OFF Y-cell
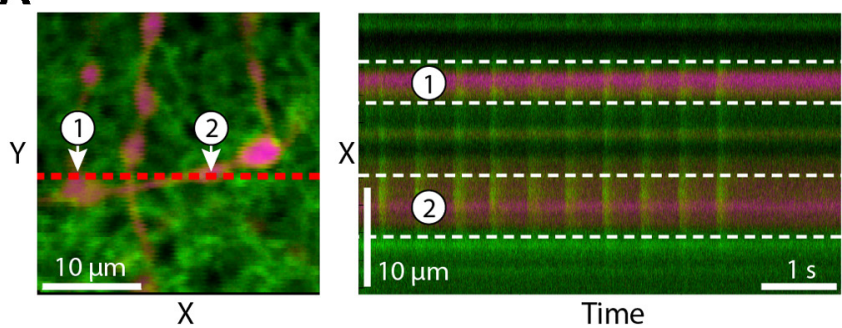

Time

C Excitatory current

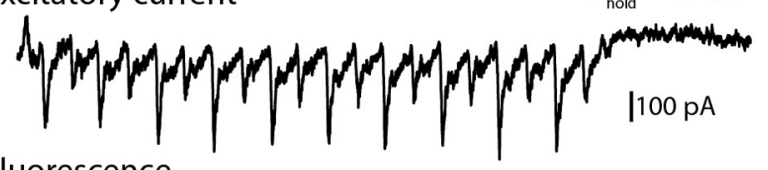

Fluorescence

(1)

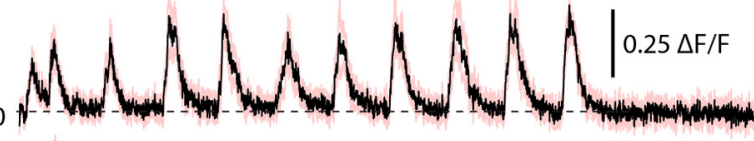

(2)
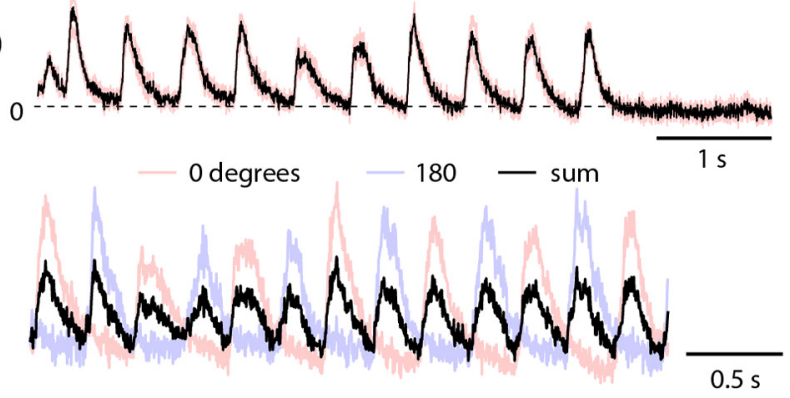

E
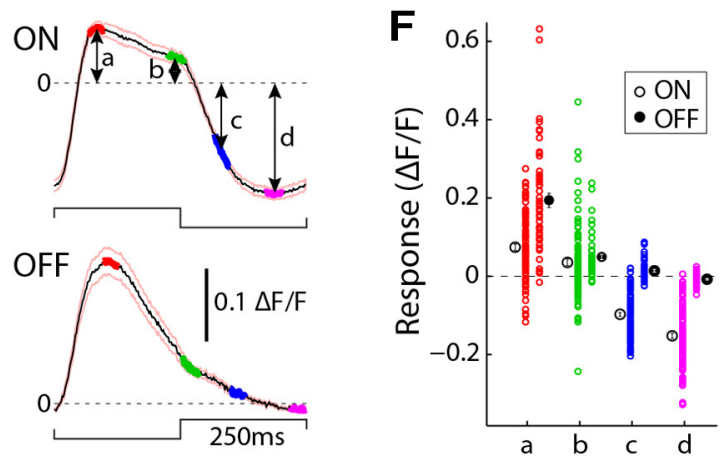
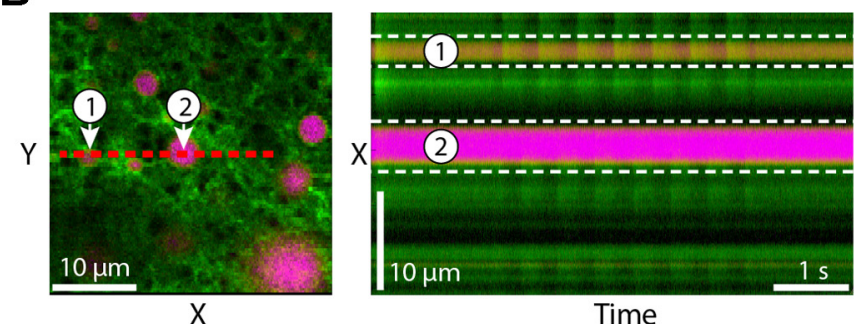

Time

D Excitatory current
G ON

Fluorescence

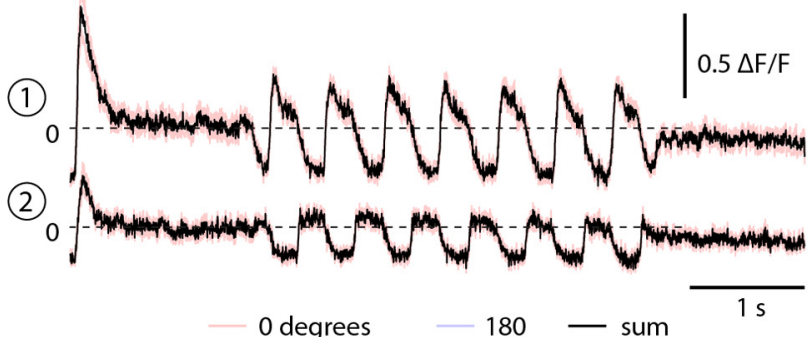

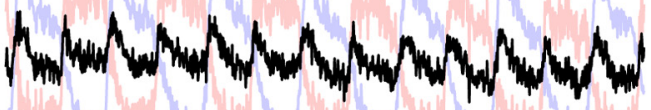

0

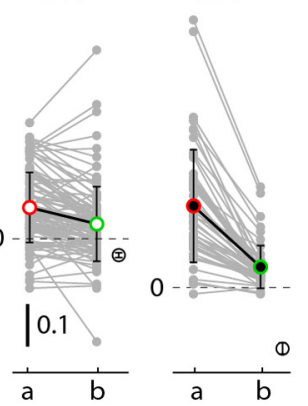

H Simulation

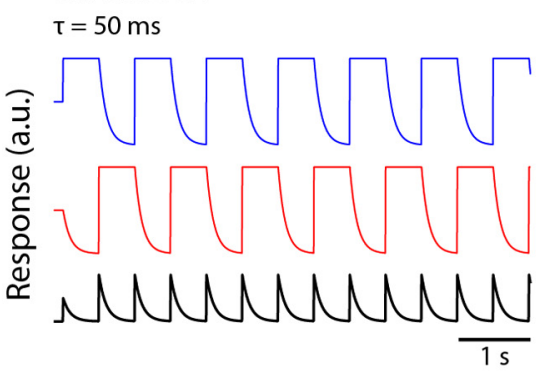

Figure 7. Glutamate release in the ON Y-cell layer is less rectified and more sustained compared with the OFF Y-cell layer. $A$, Two-photon fluorescence image of the scan location (left) and light-evoked responses at this location recorded with line scans ( $2 \mathrm{kHz}$ sampling; right). The line scan (dashed red line) intersects two dendrites of the simultaneously recorded $0 \mathrm{FF} Y$-cell (magenta). $B$, Same as $\boldsymbol{A}$, for an $0 \mathrm{~N} Y$-cell. C, Top row, Excitatory currents recorded from the $0 \mathrm{FF} Y$-cell shown in $\boldsymbol{A}$ during stimulation with contrast-reversing gratings $(10 \mathrm{cycles} / \mathrm{mm}, 2 \mathrm{~Hz})$. The difference in the response amplitude in alternate contrast-reversals suggests a slight imbalance in the number of bars stimulating the receptive field during alternate reversals. Middle rows, Fluorescence changes at two locations (1, 2 shown in $\boldsymbol{A})$ on the dendrites recorded simultaneously with the currents. Here and in subsequent panels, SEM of fluorescence measurements is shown in pink. Bottom row (black), Sum of the normalized responses of two bipolar cell populations with opposite phase (red, blue $=$ ROls 1 and 2 shown above). D, Same as C, for an ON Y-cell. E, Average fluorescence response recorded with line scans across the dendrites of ONY-cells after a light increment (left; $n=108$ ) and OFF Y-cells after a light decrement (right; $n=54$ ). Stimulus time course shown below each trace. Response waveforms were quantified by averaging the fluorescence signal in each colored region. $\boldsymbol{F}$, Distribution and average \pm SEM of the four measurements shown in $\boldsymbol{E}$. $\boldsymbol{G}$, Fluorescence change from the response just after stimulus onset $\left(a, t_{\text {peak }}\right)$ to the response just before stimulus offset $\left(b, t_{\text {peak }}+160 \mathrm{~ms}\right)$ shows that responses in the synaptic layers where $0 \mathrm{~N} Y$-cells stratify are relatively sustained. The difference between a and $b$ is shown to the right of $b$. Error bars indicate SEM across ROIs. $\boldsymbol{H}$, Simulation demonstrates how alternating sustained responses with a non-zero decay time-constant in combination generate transient responses at twice the frequency of the underlying responses.

strength of the predicted F2 response was strongest near the center of the IPL (Fig. $8 A, D$ ). Thus, there was some degree of nonlinearity at all levels of the IPL, but the nonlinearity was strongest in the central-most layers. OFF-type Y-cells stratify in the OFF layer with the strongest $\mathrm{F} 2$ response, but somewhat surprisingly, ON-type Y-cells do not stratify in the ON layer with the strongest F2 response (Fig. $8 D$ ).

\section{Discussion}

We investigated the synaptic mechanism underlying the nonlinear subunits of retinal ganglion cell receptive fields. Nonlinear subunits are a fundamental receptive field property of Y-type ganglion cells, first described at the functional level in cat (Enroth-Cugell and Robson, 1966; Hochstein and Shapley, 1976). Here, we examined non- 


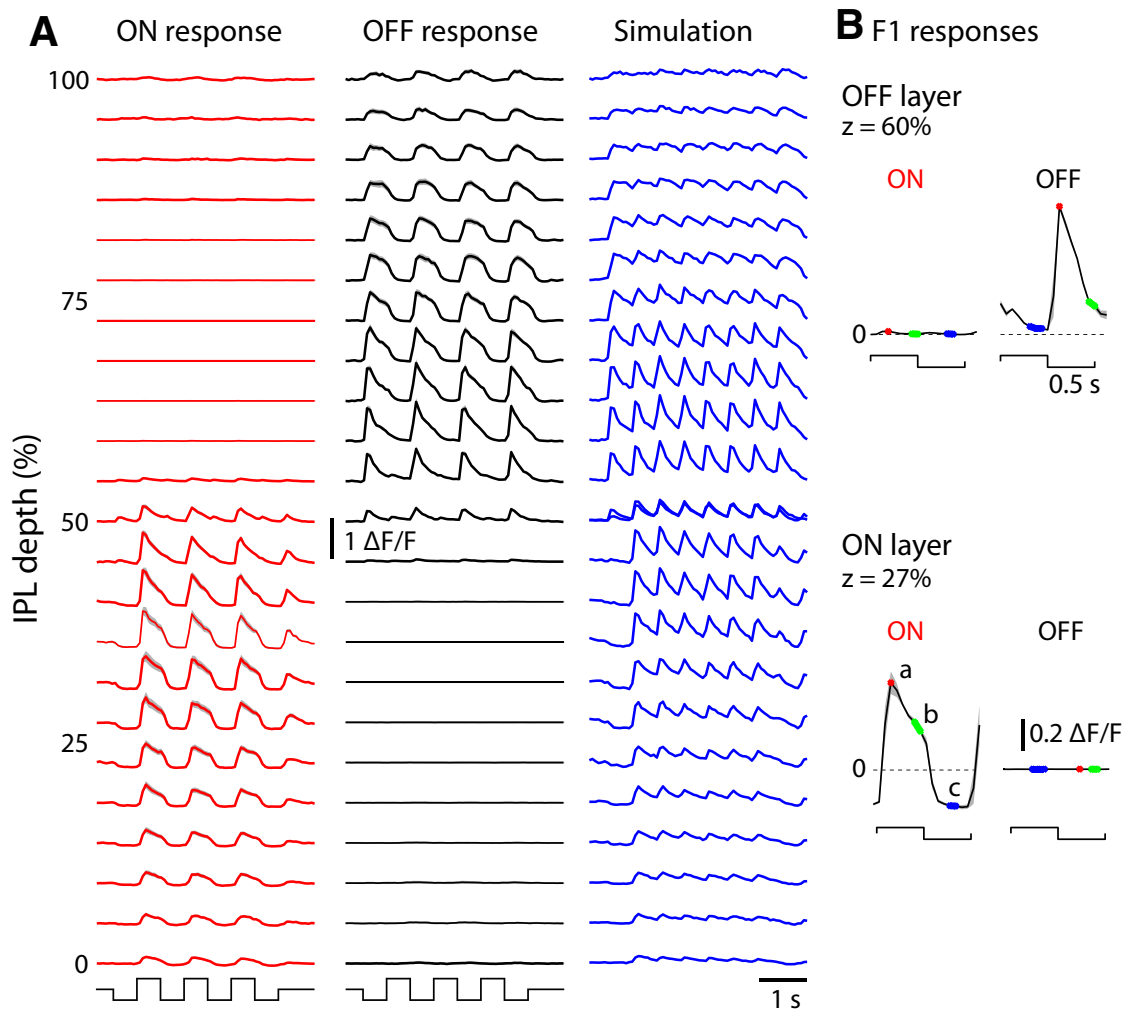

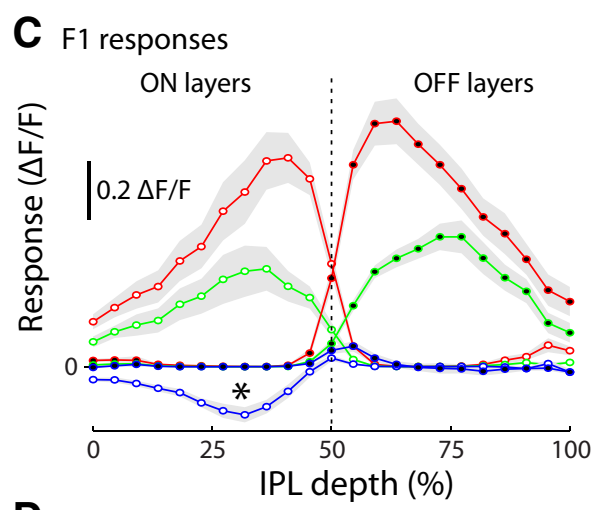

D F1 + F2 responses

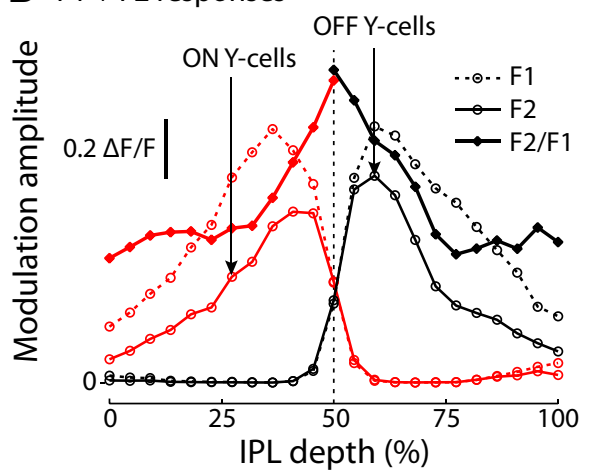

Figure 8. Temporal dynamics of bipolar cell glutamate release throughout the IPL. A, Above-threshold ON- and OFF responses (left and center, respectively; see Materials and Methods) to a small spot (150 $\mu \mathrm{m}, 1 \mathrm{~Hz}$ square-wave; bottom) recorded at 23 levels of the IPL ( $2 \mu \mathrm{m}$ spacing) and aligned to the ON/OFF boundary (50\%). Data show average of 14 stacks (see Materials and Methods for definition of ROls). Shaded areas represent SEM across stacks. Stimulus time course shown below traces. Glutamate release in response to a contrast-reversing grating, sensed by a postsynaptic cell at each level of the IPL was simulated (right) by summing the recorded responses (left and center) with their 180-degree phase-shifted copies. $\boldsymbol{B}$, Quantification of the temporal dynamics of glutamate release. Examples show two levels of the IPL: top, stratification level of OFFY-cells; bottom, stratification level of ONY-cells; a-cindicate measured sections of the response. C, Mean values of a $-c$ (defined in $B$ ) at 23 levels of the IPL. White markers represent $0 \mathrm{~N}$ responses; black markers represent OFF responses. Shaded area represents SEM; $n=14 z$-stacks. Asteriskindicates suppression of tonic glutamate release during the nonpreferred stimulus phase, which is present in $0 \mathrm{~N}$ - but not 0 FFlayers. $D$, Comparison of the measured response amplitude at the stimulus frequency ( $\mathrm{F} 1,1 \mathrm{~Hz}$; dashed line, data shown in $A$, left and center), the simulated response amplitude at twice the stimulus frequency ( $\mathrm{F2}, 2 \mathrm{~Hz}$; solid line, data shown in $A$, right), and their ratio (F2: F1).

linear subunits at the synaptic level by a combination of whole-cell recording from mouse Y-type cells and two-photon fluorescence imaging of a glutamate sensor (iGluSnFR) expressed on their dendrites and throughout the IPL (Fig. 2). Our findings support a model whereby individual bipolar cells integrate contrast linearly over their receptive field centers ( $\sim 66-81 \mu \mathrm{m}$ width; Fig. 4$)$. At the bipolar cell synaptic terminal, glutamate release undergoes a nonlinear transformation (Figs. 5 and 7).

The dominant mechanism at OFF bipolar synapses is transience and rectification. At ON synapses, the dominant mechanism is an asymmetry in the onset and offset of glutamate release. This asymmetry, which was present also at OFF synapses, may be explained by properties of the bipolar cell's glutamate receptors and, in the case of $\mathrm{ON}$ cells, related G-protein signaling pathways (DeVries et al., 2006; Xu et al., 2008; Cao et al., 2012). For both $\mathrm{ON}$ and OFF bipolar cells, release from the terminal is intrinsically nonlinear (Singer and Diamond, 2003; Jarsky et al., 2011). This nonlinearity could be augmented by amacrine cell feedback at the terminal (Freed et al., 2003; Vigh and von Gersdorff, 2005), as well as nonlinearities resulting from voltage-gated channels (e.g., Na and Ca spikes) (Protti et al., 2000; Cui and Pan, 2008; Baden et al., 2011; Saszik and DeVries, 2012). It is unclear on the basis of our measurements whether the transient nature of release observed in certain layers is the result of Ca spikes as reported in fish bipolar cells (Baden et al., 2011; Dreosti et al., 2011).

Thus, despite the difference in their degree of rectification and temporal kinetics, both ON and OFF bipolar synapses generate the characteristic nonlinear response measured in Y-cells (Fig. 7). A ganglion cell's postsynaptic glutamate receptors (Chen and Diamond, 2002; Sagdullaev et al., 2006; Manookin et al., 2010) and electrical synapses may further enhance nonlinear properties of their receptive fields (Hu and Bloomfield, 2003; Murphy and Rieke, 2011). However, our results show that the glutamate release at bipolar cell synapses alone suffices for generating the Y-cell nonlinearity (Enroth-Cugell and Freeman, 1987).

Nonlinear glutamate release was found in the specific layers where ON and OFF Y-cells stratify their dendrites, but some degree of nonlinearity was found throughout the IPL (Fig. 8A). Interestingly, a layer in the ON region $(40-50 \%$ depth; Fig. $8 A, D)$ distal to the ON Y-cell stratification level (25-30\% depth) showed simulated F2 responses that were larger than those found at the level where the ON Y-cell stratifies. This predicts that widefield ON-type ganglion cells that stratify distal to the ON Y-cells have strong nonlinear responses.

\section{Receptive field size measurements of bipolar cells}

The relatively large bipolar cell center, compared with its dendritic tree $(\sim 15-20 \mu \mathrm{m}$ width), may be partly explained by electrical coupling at the level of cones and bipolar cells (Kolb, 1979; Tsukamoto et al., 2001; DeVries et al., 2002; Hilgen et al., 2011) and lateral glutamate diffusion in the outer retina (Szmajda and DeVries, 2011). Our estimate of center size may also include an effect of glutamate spillover in the inner retina. However, the spillover detected by iGluSnFR is apparently minimal (Fig. $2 \mathrm{H}$ ). 
Our estimates of bipolar cell center width are wider than one estimate from mouse bipolar recordings ( $44 \mu \mathrm{m}$ ) (Schwartz et al., 2012) but similar to an estimate from primate diffuse bipolar recordings (65 $\mu \mathrm{m})$ (Dacey et al., 2000).

\section{Generating linear receptive fields}

Our results illustrate how ganglion cells can build nonlinear receptive fields. However, for certain visual tasks (e.g., localizing the position of small stimuli), it is advantageous to have arrays of ganglion cells with linear receptive fields, such as $\beta / \mathrm{X}$-type ganglion cells in the cat retina and the midget/parvocellular ganglion cells in monkey retina. Both of these types show essentially linear spatial integration: in response to a contrast-reversing grating, each of these cell types shows a clear null phase and lacks an F2 response (Enroth-Cugell and Robson, 1966; Hochstein and Shapley, 1976; Kaplan and Shapley, 1982; Derrington and Lennie, 1984; Petrusca et al., 2007). How would a ganglion cell build a linear receptive field?

Our data show the largest nonlinearities in release near the center of the IPL (Fig. 8), consistent with previous measurements of excitatory current in ganglion cells (Roska and Werblin, 2001) and Ca imaging of bipolar terminals (Baden et al., 2013). Thus, ganglion cells with relatively linear receptive fields might collect synapses near the IPL borders. Indeed, midget ganglion cells stratify near the edges of the IPL (Watanabe and Rodieck, 1989) where, in mouse, we found release to be most linear (Fig. 8A,D). The OFF $\delta$ cell in mouse also stratifies near the INL border, which might explain its relatively linear response (van Wyk et al., 2009; Zhang et al., 2012). Furthermore, synaptic inhibition might cancel some of the nonlinearity that is present at the level of glutamate release, making the combined input more linear (Cohen, 1998; Manookin et al., 2008; Molnar et al., 2009; Munch et al., 2009).

Another possibility is that linear ganglion cells collect inputs over a spatial region that is sufficiently narrow to contain only bipolar cells whose receptive fields overlap. As such, these bipolar cells would appear to the postsynaptic ganglion cell as a single functional subunit, with a null phase. Indeed, linear ganglion cells tend to have small receptive fields (but see Zhang et al., 2012). An extreme example is the central midget ganglion cell, which collects input from a single bipolar cell (Polyak, 1941; Kolb and Dekorver, 1991; Calkins et al., 1994). Central $\beta$ cells in cat collect synapses from a greater number of bipolar cells, 10-20 (Cohen and Sterling, 1992; Kolb and Nelson, 1993); however, the majority of synapses are made with the central-most bipolar cells (Kier et al., 1995), and each bipolar cell's receptive field diameter ( $\sim 40-80 \mu \mathrm{m}$ ) (Schwartz et al., 2012; Dacey et al., 2000; present study) is likely wider than the $\beta$ cell's dendritic tree $(30-60 \mu \mathrm{m})$ (McGuire et al., 1986; Kolb and Nelson, 1993). For ganglion cells that are relatively small, then, linearity may be a natural consequence of primarily integrating presynaptic bipolar cells with overlapping receptive fields.

\section{Advantages and limitations of measuring synaptic release with iGluSnFR}

We used the recently developed protein sensor iGluSnFR to characterize nonlinear properties of glutamatergic synapses in the inner retina. Several findings validate iGluSnFR's use in characterizing synaptic function within intact circuits. iGluSnFR fluorescence increased linearly with simultaneously recorded EPSCs (Fig. 3E). The temporal response of the sensor showed a negligible delay relative to the EPSCs (Figs. 3, 7), consistent with an earlier study (Marvin et al., 2013). Our measurements resolved the spatial pattern of grating-evoked glutamate release into $\sim 20$ $\mu \mathrm{m}$-wide regions of fluorescence increase and decrease, separated by a silent null-region (Fig. 5). This demonstrates sufficient sampling resolution at the spatial scale of bipolar axon terminals (Wässle et al., 2009). Furthermore, light-evoked responses recorded from intermingled processes at the ON/OFF boundary of the IPL divided into spatially separated ON- or OFF-responses (Fig. $2 \mathrm{H}$ ), reiterating subcellular sampling of glutamate release with minor diffusion of glutamate between nearby synaptic locations (Hartveit and Veruki, 2006; Ichinose and Lukasiewicz, 2012). The spatial resolution of iGluSnFR signals in the intact retina was similar to estimates based on experiments in hippocampal slices (from glutamate uncaging experiments) and spiny dendrites from mouse motor cortex, in vivo (Marvin et al., 2013).

iGluSnFR complements existing methods for characterizing retinal synapses. For example, whole-cell recordings of EPSCs in ganglion cells conflate presynaptic release with influences of postsynaptic glutamate receptors (e.g., AMPA vs NMDA) (Chen and Diamond, 2002; Manookin et al., 2010) and electrical synapses (Hu et al., 2010; Murphy and Rieke, 2011). Whole-cell recordings also provide no information about the spatiotemporal pattern of bipolar cell inputs to a ganglion cell's dendritic arbor because currents reflect the total input after integration at the soma. In the presynaptic bipolar cell terminal, evoked responses can be recorded with optical imaging, for example, with a genetically encoded calcium indicator (Borghuis et al., 2011; Dreosti et al., 2011; Odermatt et al., 2012). However, presynaptic calcium may not reflect synaptic release in the presence of vesicle depletion (Singer and Diamond, 2003; Jarsky et al., 2011). Hence, twophoton imaging of iGluSnFR complements the other techniques because it measures synaptic release directly and locally, and differentiates contributions of release from postsynaptic receptors. A potential drawback of iGluSnFR is that, despite a high spatial resolution, the fluorescence response reflects both synaptic and extrasynaptic release (Fig. $2 \mathrm{H}$ ); future versions of the sensor protein or genetic targeting method may address this.

\section{References}

Baccus SA, Olveczky BP, Manu M, Meister M (2008) A retinal circuit that computes object motion. J Neurosci 28:6807-6817. CrossRef Medline

Baden T, Esposti F, Nikolaev A, Lagnado L (2011) Spikes in retinal bipolar cells phase-lock to visual stimuli with millisecond precision. Curr Biol 21:1859-1869. CrossRef Medline

Baden T, Berens P, Bethge M, Euler T (2013) Spikes in mammalian bipolar cells support temporal layering of the inner retina. Curr Biol 23:48-52. CrossRef Medline

Beier KT, Borghuis BG, El-Danaf RN, Huberman AD, Demb JB, Cepko CL (2013) Transsynaptic tracing with vesicular stomatitis virus reveals novel retinal circuitry. J Neurosci 33:35-51. CrossRef Medline

Berntson A, Taylor WR (2000) Response characteristics and receptive field widths of on-bipolar cells in the mouse retina. J Physiol 524:879-889. CrossRef Medline

Borghuis BG, Tian L, Xu Y, Nikonov SS, Vardi N, Zemelman BV, Looger LL (2011) Imaging light responses of targeted neuron populations in the rodent retina. J Neurosci 31:2855-2867. CrossRef Medline

Breuninger T, Puller C, Haverkamp S, Euler T (2011) Chromatic bipolar cell pathways in the mouse retina. J Neurosci 31:6504-6517. CrossRef Medline

Brown SP, Masland RH (2001) Spatial scale and cellular substrate of contrast adaptation by retinal ganglion cells. Nat Neurosci 4:44-51. CrossRef Medline

Caldwell JH, Daw NW (1978) New properties of rabbit retinal ganglion cells. J Physiol 276:257-276. Medline

Calkins DJ, Schein SJ, Tsukamoto Y, Sterling P (1994) M and L cones in macaque fovea connect to midget ganglion cells by different numbers of excitatory synapses. Nature 371:70-72. CrossRef Medline 
Cao Y, Pahlberg J, Sarria I, Kamasawa N, Sampath AP, Martemyanov KA (2012) Regulators of G protein signaling RGS7 and RGS11 determine the onset of the light response in ON bipolar neurons. Proc Natl Acad Sci U S A 109:7905-7910. CrossRef Medline

Chang B, Dacey MS, Hawes NL, Hitchcock PF, Milam AH, Atmaca-Sonmez P, Nusinowitz S, Heckenlively JR (2006) Cone photoreceptor function loss-3, a novel mouse model of achromatopsia due to a mutation in Gnat2. Invest Ophthalmol Vis Sci 47:5017-5021. CrossRef Medline

Chang L, Breuninger T, Euler T (2013) Chromatic coding from cone-type unselective circuits in the mouse retina. Neuron 77:559-571. CrossRef Medline

Chen EY, Marre O, Fisher C, Schwartz G, Levy J, da Silviera RA, Berry MJ 2nd (2013) Alert response to motion onset in the retina. J Neurosci 33:120132. CrossRef Medline

Chen S, Diamond JS (2002) Synaptically released glutamate activates extrasynaptic NMDA receptors on cells in the ganglion cell layer of rat retina. J Neurosci 22:2165-2173. Medline

Cohen E, Sterling P (1992) Parallel circuits from cones to the on-beta ganglion cell. Eur J Neurosci 4:506-520. CrossRef Medline

Cohen ED (1998) Interactions of inhibition and excitation in the lightevoked currents of X type retinal ganglion cells. J Neurophysiol 80: 2975-2990. Medline

Crook JD, Peterson BB, Packer OS, Robinson FR, Troy JB, Dacey DM (2008) Y-cell receptive field and collicular projection of parasol ganglion cells in macaque monkey retina. J Neurosci 28:11277-11291. CrossRef Medline

Cui J, Pan ZH (2008) Two types of cone bipolar cells express voltage-gated $\mathrm{Na}^{+}$channels in the rat retina. Vis Neurosci 25:635-645. CrossRef Medline

Dacey D, Packer OS, Diller L, Brainard D, Peterson B, Lee B (2000) Center surround receptive field structure of cone bipolar cells in primate retina. Vision Res 40:1801-1811. CrossRef Medline

Demb JB, Haarsma L, Freed MA, Sterling P (1999) Functional circuitry of the retinal ganglion cell's nonlinear receptive field. J Neurosci 19:9756-9767. Medline

Demb JB, Zaghloul K, Sterling P (2001a) Cellular basis for the response to second-order motion cues in Y retinal ganglion cells. Neuron 32:711-721. CrossRef Medline

Demb JB, Zaghloul K, Haarsma L, Sterling P (2001b) Bipolar cells contribute to nonlinear spatial summation in the brisk-transient $(\mathrm{Y})$ ganglion cell in mammalian retina. J Neurosci 21:7447-7454. Medline

Derrington AM, Lennie P (1984) Spatial and temporal contrast sensitivities of neurones in lateral geniculate nucleus of macaque. J Physiol 357:219-240. Medline

DeVries SH, Qi X, Smith R, Makous W, Sterling P (2002) Electrical coupling between mammalian cones. Curr Biol 12:1900-1907. CrossRef Medline

DeVries SH, Li W, Saszik S (2006) Parallel processing in two transmitter microenvironments at the cone photoreceptor synapse. Neuron 50:735-748. CrossRef Medline

Dong CY, Koenig K, So P (2003) Characterizing point spread functions of two-photon fluorescence microscopy in turbid medium. J Biomed Optics 8:450-459. CrossRef Medline

Dreosti E, Esposti F, Baden T, Lagnado L (2011) In vivo evidence that retinal bipolar cells generate spikes modulated by light. Nat Neurosci 14:951-952. CrossRef Medline

Eggers ED, McCall MA, Lukasiewicz PD (2007) Presynaptic inhibition differentially shapes transmission in distinct circuits in the mouse retina. J Physiol 582:569-582. CrossRef Medline

Enroth-Cugell C, Freeman AW (1987) The receptive-field spatial structure of cat retinal Y cells. J Physiol 384:49-79. Medline

Enroth-Cugell C, Robson JG (1966) The contrast sensitivity of retinal ganglion cells of the cat. J Physiol 187:517-552. Medline

Estevez ME, Fogerson PM, Ilardi MC, Borghuis BG, Chan E, Weng S, Auferkorte ON, Demb JB, Berson DM (2012) Form and function of the M4 cell, an intrinsically photosensitive retinal ganglion cell type contributing to geniculocortical vision. J Neurosci 32:13608-13620. CrossRef Medline

Euler T, Wässle H (1998) Different contributions of GABAA and GABAC receptors to rod and cone bipolar cells in a rat retinal slice preparation. J Neurophysiol 79:1384-1395. Medline

Euler T, Hausselt SE, Margolis DJ, Breuninger T, Castell X, Detwiler PB, Denk W (2009) Eyecup scope-optical recordings of light stimulus-evoked fluorescence signals in the retina. Pflugers Arch 457:1393-1414. CrossRef Medline
Field GD, Chichilnisky EJ (2007) Information processing in the primate retina: circuitry and coding. Annu Rev Neurosci 30:1-30. CrossRef Medline

Flores-Herr N, Protti DA, Wässle H (2001) Synaptic currents generating the inhibitory surround of ganglion cells in the mammalian retina. J Neurosci 21:4852-4863. Medline

Freed MA, Smith RG, Sterling P (2003) Timing of quantal release from the retinal bipolar terminal is regulated by a feedback circuit. Neuron 38:89101. CrossRef Medline

Garvert MM, Gollisch T (2013) Local and global contrast adaptation in retinal ganglion cells. Neuron 77:915-928. CrossRef Medline

Gaudiano P (1992) A unified neural network model of spatiotemporal processing in $\mathrm{X}$ and $\mathrm{Y}$ retinal ganglion cells: II. Temporal adaptation and simulation of experimental data. Biol Cybernetics 67:23-34. CrossRef Medline

Hartveit E, Veruki ML (2006) Studying properties of neurotransmitter receptors by non-stationary noise analysis of spontaneous synaptic currents. J Physiol 574:751-785. CrossRef Medline

Haverkamp S, Wässle H, Duebel J, Kuner T, Augustine GJ, Feng G, Euler T (2005) The primordial, blue-cone color system of the mouse retina. J Neurosci 25:5438-5445. CrossRef Medline

Hennig MH, Funke K, Wörgötter F (2002) The influence of different retinal subcircuits on the nonlinearity of ganglion cell behavior. J Neurosci 22: 8726-8738. Medline

Hilgen G, von Maltzahn J, Willecke K, Weiler R, Dedek K (2011) Subcellular distribution of connexin 45 in OFF bipolar cells of the mouse retina. J Comp Neurol 519:433-450. CrossRef Medline

Hochstein S, Shapley RM (1976) Linear and nonlinear spatial subunits in Y cat retinal ganglion cells. J Physiol 262:265-284. Medline

Hu EH, Bloomfield SA (2003) Gap junctional coupling underlies the shortlatency spike synchrony of retinal $\alpha$ ganglion cells. J Neurosci 23:67686777. Medline

Hu EH, Pan F, Völgyi B, Bloomfield SA (2010) Light increases the gap junctional coupling of retinal ganglion cells. J Physiol 588:4145-4163. CrossRef Medline

Ichinose T, Lukasiewicz PD (2012) The mode of retinal presynaptic inhibition switches with light intensity. J Neurosci 32:4360-4371. CrossRef Medline

Jackman SL, Choi SY, Thoreson WB, Rabl K, Bartoletti TM, Kramer RH (2009) Role of the synaptic ribbon in transmitting the cone light response. Nat Neurosci 12:303-310. CrossRef Medline

Jarsky T, Cembrowski M, Logan SM, Kath WL, Riecke H, Demb JB, Singer JH (2011) A synaptic mechanism for retinal adaptation to luminance and contrast. J Neurosci 31:11003-11015. CrossRef Medline

Kaplan E, Shapley RM (1982) X and Y cells in the lateral geniculate nucleus of macaque monkeys. J Physiol 330:125-143. Medline

Kier CK, Buchsbaum G, Sterling P (1995) How retinal microcircuits scale for ganglion cells of different size. J Neurosci 15:7673-7683. Medline

Kolb H (1979) The inner plexiform layer in the retina of the cat: electron microscopic observations. J Neurocytol 8:295-329. CrossRef Medline

Kolb H, Dekorver L (1991) Midget ganglion cells of the parafovea of the human retina: a study by electron microscopy and serial section reconstructions. J Comp Neurol 303:617-636. CrossRef Medline

Kolb H, Nelson R (1993) OFF-alpha and OFF-beta ganglion cells in cat retina. II. Neural circuitry as revealed by electron microscopy of HRP stains. J Comp Neurol 329:85-110. CrossRef Medline

Manookin MB, Beaudoin DL, Ernst ZR, Flagel LJ, Demb JB (2008) Disinhibition combines with excitation to extend the operating range of the OFF visual pathway in daylight. J Neurosci 28:4136-4150. CrossRef Medline

Manookin MB, Weick M, Stafford BK, Demb JB (2010) NMDA receptor contributions to visual contrast coding. Neuron 67:280-293. CrossRef Medline

Margolis DJ, Detwiler PB (2007) Different mechanisms generate maintained activity in ON and OFF retinal ganglion cells. J Neurosci 27:59946005. CrossRef Medline

Marvin JS, Borghuis BG, Tian L, Cichon J, Harnett MT, Akerboom J, Gordus A, Renninger SL, Chen TW, Bargmann CI, Orger MB, Schreiter ER, Demb JB, Gan WB, Hires SA, Looger LL (2013) An optimized fluorescent probe for visualizing glutamate neurotransmission. Nat Methods 10:162-170. CrossRef Medline

Masland RH (2012) The neuronal organization of the retina. Neuron 76: 266-280. CrossRef Medline 
McGuire BA, Stevens JK, Sterling P (1986) Microcircuitry of $\beta$ ganglion cells in cat retina. J Neurosci 6:907-918. Medline

Molnar A, Hsueh HA, Roska B, Werblin FS (2009) Crossover inhibition in the retina: circuitry that compensates for nonlinear rectifying synaptic transmission. J Comput Neurosci 27:569-590. CrossRef Medline

Münch TA, da Silveira RA, Siegert S, Viney TJ, Awatramani GB, Roska B (2009) Approach sensitivity in the retina processed by a multifunctional neural circuit. Nat Neurosci 12:1308-1316. CrossRef Medline

Murphy GJ, Rieke F (2011) Electrical synaptic input to ganglion cells underlies differences in the output and absolute sensitivity of parallel retinal circuits. J Neurosci 31:12218-12228. CrossRef Medline

Naarendorp F, Esdaille TM, Banden SM, Andrews-Labenski J, Gross OP, Pugh EN Jr (2010) Dark light, rod saturation, and the absolute and incremental sensitivity of mouse cone vision. J Neurosci 30:12495-12507. CrossRef Medline

Nikonov SS, Kholodenko R, Lem J, Pugh EN Jr (2006) Physiological features of the $\mathrm{S}$ - and $\mathrm{M}$-cone photoreceptors of wild-type mice from singlecell recordings. J Gen Physiol 127:359-374. CrossRef Medline

Odermatt B, Nikolaev A, Lagnado L (2012) Encoding of luminance and contrast by linear and nonlinear synapses in the retina. Neuron 73:758773. CrossRef Medline

Olveczky BP, Baccus SA, Meister M (2003) Segregation of object and background motion in the retina. Nature 423:401-408. CrossRef Medline

Olveczky BP, Baccus SA, Meister M (2007) Retinal adaptation to object motion. Neuron 56:689-700. CrossRef Medline

Petrusca D, Grivich MI, Sher A, Field GD, Gauthier JL, Greschner M, Shlens J, Chichilnisky EJ, Litke AM (2007) Identification and characterization of a Y-like primate retinal ganglion cell type. J Neurosci 27:11019-11027. CrossRef Medline

Polyak SL (1941) The retina. Chicago: University of Chicago.

Pourcho RG, Goebel DJ (1983) Neuronal subpopulations in cat retina which accumulate the GABA agonist, $(3 \mathrm{H})$ muscimol: a combined Golgi and autoradiographic study. J Comp Neurol 219:25-35. CrossRef Medline

Protti DA, Flores-Herr N, von Gersdorff H (2000) Light evokes $\mathrm{Ca}^{2+}$ spikes in the axon terminal of a retinal bipolar cell. Neuron 25:215-227. CrossRef Medline

Rodieck RW (1965) Quantitative analysis of cat retinal ganglion cell response to visual stimuli. Vis Res 5:583-601. CrossRef Medline

Roska B, Werblin F (2001) Vertical interactions across ten parallel, stacked representations in the mammalian retina. Nature 410:583-587. CrossRef Medline

Sagdullaev BT, McCall MA, Lukasiewicz PD (2006) Presynaptic inhibition modulates spillover, creating distinct dynamic response ranges of sensory output. Neuron 50:923-935. CrossRef Medline

Saszik S, DeVries SH (2012) A mammalian retinal bipolar cell uses both graded changes in membrane voltage and all-or-nothing $\mathrm{Na}^{+}$spikes to encode light. J Neurosci 32:297-307. CrossRef Medline

Schneeweis DM, Schnapf JL (1999) The photovoltage of macaque cone photoreceptors: adaptation, noise, and kinetics. J Neurosci 19:1203-1216. Medline

Schwartz G, Rieke F (2011) Perspectives on: information and coding in mammalian sensory physiology: nonlinear spatial encoding by retinal ganglion cells: when $1+1$ not equal 2. J Gen Physiol 138:283-290. CrossRef Medline

Schwartz GW, Okawa H, Dunn FA, Morgan JL, Kerschensteiner D, Wong RO, Rieke F (2012) The spatial structure of a nonlinear receptive field. Nat Neurosci 15:1572-1580. CrossRef Medline

Shelley J, Dedek K, Schubert T, Feigenspan A, Schultz K, Hombach S, Wil- lecke K, Weiler R (2006) Horizontal cell receptive fields are reduced in connexin57-deficient mice. Eur J Neurosci 23:3176-3186. CrossRef Medline

Shields CR, Tran MN, Wong RO, Lukasiewicz PD (2000) Distinct ionotropic GABA receptors mediate presynaptic and postsynaptic inhibition in retinal bipolar cells. J Neurosci 20:2673-2682. Medline

Singer JH, Diamond JS (2003) Sustained $\mathrm{Ca}^{2+}$ entry elicits transient postsynaptic currents at a retinal ribbon synapse. J Neurosci 23:10923-10933. Medline

Stone C, Pinto LH (1993) Response properties of ganglion cells in the isolated mouse retina. Vis Neurosci 10:31-39. CrossRef Medline

Szél A, Röhlich P, Caffé AR, Juliusson B, Aguirre G, Van Veen T (1992) Unique topographic separation of two spectral classes of cones in the mouse retina. J Comp Neurol 325:327-342. CrossRef Medline

Szmajda BA, Devries SH (2011) Glutamate spillover between mammalian cone photoreceptors. J Neurosci 31:13431-13441. CrossRef Medline

Trong PK, Rieke F (2008) Origin of correlated activity between parasol retinal ganglion cells. Nat Neurosci 11:1343-1351. CrossRef Medline

Troy JB, Einstein G, Schuurmans RP, Robson JG, Enroth-Cugell C (1989) Responses to sinusoidal gratings of two types of very nonlinear retinal ganglion cells of cat. Vis Neurosci 3:213-223. CrossRef Medline

Troy JB, Schweitzer-Tong DE, Enroth-Cugell C (1995) Receptive-field properties of Q retinal ganglion cells of the cat. Vis Neurosci 12:285-300. CrossRef Medline

Tsukamoto Y, Morigiwa K, Ueda M, Sterling P (2001) Microcircuits for night vision in mouse retina. J Neurosci 21:8616-8623. Medline

van Wyk M, Wässle H, Taylor WR (2009) Receptive field properties of ONand OFF-ganglion cells in the mouse retina. Vis Neurosci 26:297-308. CrossRef Medline

Vaney DI (1990) The mosaic of amacrine cells in the mammalian retina. Prog Retinal Res 9:49-100. CrossRef

Victor JD, Shapley RM (1979) The nonlinear pathway of Y ganglion cells in the cat retina. J Gen Physiol 74:671-689. CrossRef Medline

Vigh J, von Gersdorff H (2005) Prolonged reciprocal signaling via NMDA and GABA receptors at a retinal ribbon synapse. J Neurosci 25:11412-11423. CrossRef Medline

Wang YV, Weick M, Demb JB (2011) Spectral and temporal sensitivity of cone-mediated responses in mouse retinal ganglion cells. J Neurosci 31: 7670-7681. CrossRef Medline

Wässle H, Puller C, Müller F, Haverkamp S (2009) Cone contacts, mosaics, and territories of bipolar cells in the mouse retina. J Neurosci 29:106-117. CrossRef Medline

Watanabe M, Rodieck RW (1989) Parasol and midget ganglion cells of the primate retina. J Comp Neurol 289:434-454. CrossRef Medline

Xu Y, Sulaiman P, Feddersen RM, Liu J, Smith RG, Vardi N (2008) Retinal ON bipolar cells express a new PCP2 splice variant that accelerates the light response. J Neurosci 28:8873-8884. CrossRef Medline

Zaghloul KA, Boahen K, Demb JB (2003) Different circuits for ON and OFF retinal ganglion cells cause different contrast sensitivities. J Neurosci 23: 2645-2654. Medline

Zaghloul KA, Manookin MB, Borghuis BG, Boahen K, Demb JB (2007) Functional circuitry for peripheral suppression in mammalian Y-type retinal ganglion cells. J Neurophysiol 97:4327-4340. CrossRef Medline

Zhang J, Li W, Hoshi H, Mills SL, Massey SC (2005) Stratification of $\alpha$ ganglion cells and ON/OFF directionally selective ganglion cells in the rabbit retina. Vis Neurosci 22:535-549. CrossRef Medline

Zhang Y, Kim IJ, Sanes JR, Meister M (2012) The most numerous ganglion cell type of the mouse retina is a selective feature detector. Proc Natl Acad Sci U S A 109:E2391-E2398. CrossRef Medline 